zeszyt 151, 2017, 27-51

doi: 10.4467/20833113PG.17.021.8033

Instytut Geografii i Gospodarki Przestrzennej UJ

Wydawnictwo Uniwersytetu Jagiellońskiego

\title{
POWÓDŹ BŁYSKAWICZNA JAKO ZDARZENIE PRZYRODNICZE I SPOŁECZNE NA PRZYKŁADZIE POWODZI W WOJCIESZOWIE 5 LIPCA 2012 ROKU
}

\author{
Pawet Franczak, Lukasz Fieden, Karolina Grzeszna, \\ Jarostaw Dziatek, Wojciech Biernacki
}

\section{Flash flood as a natural and social event - the case of the flood in Wojcieszów, on July 5th, 2012}

Abstract: By definition, a flood is a natural event with social and economic consequences. These effects can be both direct and immediate as flood losses, as well as indirect and long-lasting, influencing local community's perception of the geographical environment they live in and of possible local disasters. Flash floods in mountainous areas constitute a particular type of hazard. They appear when intense rainfall over a small area causes violent and destructive flooding. Such an event occurred on July 5th, 2012 in the upper Kaczawa catchment when heavy rainfall formed sudden overflowing in small river and stream catchments in the town of Wojcieszów (Złotoryja county, Dolnośląskie voivodship in Poland). Precipitation was characterized by a very high intensity up to $69 \mathrm{~mm} \cdot \mathrm{h}^{-1}$ with the daily sum reaching $94 \mathrm{~mm}$. Such high rainfall occurred on a very small area stretching $25 \mathrm{~km}$ in length and $10-12 \mathrm{~km}$ in width. It caused a very rapid concentration of flood wave with the culmination reached within 30-40 min. after the most intense precipitation. The flow of Kaczawa river in Świerzawa reached $115 \mathrm{~m}^{3} \cdot \mathrm{s}^{-1}\left(\mathrm{q}_{\max }=0,86 \mathrm{~m}^{3} \cdot \mathrm{s}^{-1} \cdot \mathrm{km}^{2}\right)$, though it did not stand out from historic floods in this catchment. Much higher specific discharges were measured for the Kaczawa catchment in Wojcieszów Dolny $\left(1.95 \mathrm{~m}^{3} \cdot \mathrm{s}^{-1} \cdot \mathrm{km}^{2}\right)$ and for the Olszanka catchment $\left(2.06 \mathrm{~m}^{3} \cdot \mathrm{s}^{-1} \cdot \mathrm{km}^{2}\right)$. The overflow of water in smaller catchments was catastrophic and caused considerable damage. The main aim of the paper is to analyse the social memory of the 2012 flash flood in Wojcieszów several years after its occurrence. The research included mental sketch mapping of flooded areas conducted two and four years after the flood happened and an analysis of flood recordings available on the YouTube video-sharing website. The findings show that, despite being surprised by the sudden flood that hit their town, memories about that event 
are slowly fading away. With time passing by, flood witnesses tend to mark a progressively smaller than actual area covered by flood waters. They are not likely to watch historic flood recordings on YouTube either. The authors believe that the decline of social memories of the flood may translate into lower hazard awareness resulting in inadequate preparedness for a possible future flood.

Keywords: flash flood, social memory of floods, mental sketch mapping, social media

Zarys treści: Powódź to z definicji zdarzenie przyrodnicze, które ma konsekwencje społeczne i ekonomiczne. Skutki te mogą być zarówno bezpośrednie i natychmiastowe w postaci zniszczeń wywołanych przez wezbrane wody, jak również pośrednie i długotrwałe w postaci wyobrażeń o środowisku geograficznym oraz o zdarzeniach ekstremalnych, które mogą wystąpić na danym obszarze. Szczególny rodzaj zagrożenia stanowią powodzie błyskawiczne w obszarach górskich, gdy intensywne opady na niewielkim obszarze wywołują gwałtowną w przebiegu i skutkach powódź. Do takiego zdarzenia doszło 5 lipca 2012 r. w zlewni górnej Kaczawy, kiedy intensywne opady doprowadziły do uformowania gwałtownych wezbrań w małych zlewniach na obszarze Wojcieszowa (powiat złotoryjski, województwo dolnośląskie). Charakteryzowały się one bardzo dużym natężeniem, które dochodziło do $69 \mathrm{~mm} \cdot \mathrm{h}^{-1}$, a dobowa suma opadu przekroczyła $94 \mathrm{~mm}$. Tak wysokie opady wystąpiły na bardzo niewielkim obszarze rozciągającym się w pasie o długości $25 \mathrm{~km}$ i szerokości $10-12 \mathrm{~km}$. Spowodowały bardzo szybkie uformowanie fali wezbraniowej, której kulminacja osiągnięta została w ciągu 30-40 minut od wystąpienia najintensywniejszych opadów. Przepływ Kaczawy w Świerzawie wzrósł do $115 \mathrm{~m}^{3} \cdot \mathrm{s}^{-1}\left(\mathrm{q}_{\max }-0,86 \mathrm{~m}^{3} \cdot \mathrm{s}^{-1} \cdot \mathrm{km}^{2}\right)$ i nie wyróżniał się na tle innych wezbrań, które wystąpiły w zlewni w przeszłości. Znacznie wyższy maksymalny odpływ jednostkowy odnotowano w zlewni Kaczawy po profil w Dolnym Wojcieszowie $\left(1,95 \mathrm{~m}^{3} \cdot \mathrm{s}^{-1} \cdot \mathrm{km}^{2}\right)$ oraz w zlewni Olszanki $\left(2,06 \mathrm{~m}^{3} \cdot \mathrm{s}^{-1} \cdot \mathrm{km}^{2}\right)$. W małych zlewniach wezbranie osiągnęło katastrofalne rozmiary i wyrządziło znaczne straty. Celem artykułu jest określenie pamięci społecznej o powodzi błyskawicznej w Wojcieszowie z 2012 r. w kilka lat po jej wystąpieniu. Dokonano tego na podstawie badania wyobrażeń przestrzennych o zasięgu wód powodziowych przeprowadzonych dwa i cztery lata po jej wystąpieniu oraz analizy materiałów filmowych o powodzi dostępnych w serwisie internetowym YoúTube. Wyniki wskazują, że pomimo zaskoczenia gwałtownym przebiegiem powodzi, to pamięć o niej stopniowo zanika. Świadkowie powodzi wraz z upływem czasu od katastrofalnego zjawiska mają tendencję do wskazywania mniejszego niż rzeczywisty zasięgu wód wezbraniowych. Nie powracają również do materiałów o powodzi dostępnych w serwisie YouTube. Zanikanie pamięci społecznej o katastrofalnym zdarzeniu może przekładać się na niską świadomość zagrożenia powodziowego, a w konsekwencji na niski stopień przygotowania mieszkańców do kolejnego potencjalnego zdarzenia.

Stowa kluczowe: powódź błyskawiczna, pamięć społeczna o powodzi, mapy wyobrażeniowe, media społecznościowe

\section{Wprowadzenie}

Powodzie błyskawiczne charakteryzują się bardzo szybkim przebiegiem, a czas koncentracji fali powodziowej wynosi do kilku godzin po wystąpieniu nawalnych 
opadów. Występują one w małych zlewniach objętych zasięgiem krótkotrwałych (trwających do kilku godzin), lecz bardzo intensywnych opadów deszczu (Parczewski 1960; Pociask-Karteczka, Żychowski 2014; Romanowicz i in. 2014). Ich zasięg przeważnie nie przekracza $100 \mathrm{~km}^{2}$, a w połowie przypadków tego rodzaju powodzi obszar tych opadów nie osiąga 25 km² (Lenart 1993; Bryndal 2010), w związku z czym gwałtowne wezbrania występują w obrębie jednej bądź maksymalnie kilku przylegających do siebie małych zlewni. Ich negatywne skutki społeczno-ekonomiczne są zatem z reguły lokalne, ale skala destrukcji i wielkość strat mogą być znaczące. Wystąpienie tego rodzaju powodzi (dokładne określenie miejsca i czasu) jest jednocześnie trudne do przewidzenia, co przekłada się na ograniczone możliwości ostrzegania mieszkańców terenów zagrożonych, wpływając tym samym na wielkość szkód i liczbę ofiar tych zdarzeń (Ruin i in. 2007; Hong i in. 2013).

Badania nad tym, jak ludzie postrzegają różnego rodzaju zagrożenia przyrodnicze, wskazują na szereg złożonych uwarunkowań, które mają wpływ na ten proces: związane są albo z charakterem samego zjawiska, albo z cechami ludźmi na niego narażonymi (Ruin i in. 2007; Wachinger, Renn 2010; Rucińska 2012). Podkreślane jest w tym zakresie znaczenie cech danego zjawiska ekstremalnego, jego skala, przebieg, zasięg czasowy i przestrzenny. Klasyczne badania postrzegania ryzyka (Covello 1991; Smith 2001) wskazują, że zdarzenia skoncentrowane w czasie i przestrzeni, które z trudem poddają się kontroli człowieka, czyli takie jak powodzie błyskawiczne, są odczuwane przez ludzi jako bardziej im zagrażające. Jednocześnie te same badania wskazują, że zjawiska, które przynoszą natychmiastowe skutki, oraz takie, których mechanizm jest stosunkowo zrozumiały (jak w przypadku powodzi błyskawicznych: gwałtowne opady - nagłe wezbranie wód), są w większym stopniu przez ludzi lekceważone, co skutkuje brakiem odpowiedniego przygotowania do nich.

Drugi nurt badań wskazuje na znaczenie uprzedniego doświadczenia klęski żywiołowej w postrzeganiu możliwości ponownego jej wystąpienia. Osoby, które przeżyły powódź, z reguły częściej podejmują działania zapobiegawcze (Siegrist, Gutscher 2008; Wachinger, Renn 2010; Rufat i in. 2015; Konieczny i in. 2016). Postrzeganie ryzyka i skłonność do zabezpieczania się przed zagrożeniem osiągają jednak wysoki poziom bezpośrednio po powodzi, a z czasem stopniowo zanikają (Felgentreff 2003). Należy rozróżnić przy tym obszary, w których doszło do pojedynczych zdarzeń o wyjątkowo dużej skali i gwałtownym przebiegu, od obszarów nawiedzanych częściej, ale przez powodzie o mniejszej skali. Okazuje się, że w tym pierwszym przypadku gotowość do podejmowania działań zabezpieczających przed konsekwencjami kolejnego zdarzenia, które może wystąpić w danym miejscu, jest niższa (Tobin, Burrel 1997; Biernacki i in. 2009; Renn 2008). Z taką sytuacją można mieć do czynienia m.in. w przypadku powodzi błyskawicznych.

Mechanizmy odpowiadające za percepcję ryzyka wpływają na kształtowanie się pamięci społecznej o powodzi. W społecznościach nawiedzanych przez klęski żywio- 
łowe nie funkcjonują one jako „obiektywne zdarzenia, a raczej subiektywne, które mogą być wzmacniane lub wymazywane w zależności od tego, jak działają procesy selektywnego zapamiętywania lub kolektywnego zapominania" (Bankoff 2004: 34). Pamięć o historycznych powodziach tworzą zatem różnego rodzaju wyobrażenia o nich, czyli (inter)subiektywne opinie na temat ich przyczyn, przebiegu i konsekwencjach. Są one tworzone na podstawie własnych doświadczeń, a także oparte na przekazie społecznym i medialnym. Przechowywana pamięć o minionych katastrofach stanowi istotny element budowania odporności (resilience) społeczności lokalnych na klęski żywiołowe, czyli społecznych zdolności (social capacities) do odpowiedniego przygotowania się do nich, reagowania na nie i odbudowy po ich wystąpieniu (Colten, Sumpter 2009; Wilson 2013; Kuhlicke, Steinführer 2015). W tym kontekście wskazuje się, że współcześnie pamięć społeczna o zagrożeniach przyrodniczych w coraz bardziej zurbanizowanych i mobilnych społeczeństwach ulega osłabieniu ze względu na ograniczenia przekazu międzypokoleniowego, co określane jest mianem amnezji zagrożeniowej (Rucińska 2014).

Przedmiotem analiz w niniejszym artykule jest zdarzenie o charakterze powodzi błyskawicznej, do którego doszło na Kaczawie 5 lipca 2012 r., a które największe straty przyniosło w Wojcieszowie, w powiecie złotoryjskim, w województwie dolnośląskim. Celem opracowania jest określenie, w jakim stopniu powódź ta zapisała się w pamięci społecznej mieszkańców miasta w kontekście jej gwałtownego przebiegu i wcześniejszych historycznych zdarzeń. Czy, zgodnie z przedstawionymi rozważaniami, ze względu na swój burzliwy rozwój tkwi ona w pamięci mieszkańców, czy wprost przeciwnie - wyjątkowy charakter tego zdarzenia sprawił, że potraktowane zostało jako odstępstwo od reguły, nie zapisując się znacząco w ich wspomnieniach? Aby tego dokonać, najpierw przedstawiona zostanie interpretacja hydrometeorologiczna tego wezbrania, a następnie - na podstawie różnych metod badań społecznych - określone zostaną wyobrażenia i stan pamięci społecznej o tej powodzi kilka lat po jej wystąpieniu.

Prezentowane wyniki zebrano w trakcie badań przeprowadzonych w ramach projektu „Społeczno-ekonomiczne uwarunkowania wrażliwości społecznej na powódź, ze szczególnym uwzględnieniem roli komunikacji w jej kształtowaniu”, finansowanego ze środków Narodowego Centrum Nauki przyznanych na podstawie umowy numer UMO-2012/05/D/HS4/013281.

\section{Charakterystyka obszaru badawezego}

Wojcieszów to gmina miejska położona w powiecie złotoryjskim, w województwie dolnośląskim. Pod koniec 2015 r. miasto zamieszkiwało 3760 osób (BDL GUS).

\footnotetext{
${ }^{1}$ Szersze opracowanie wyników tego projektu zawarte jest w publikacji Działek i in. (2017).
} 


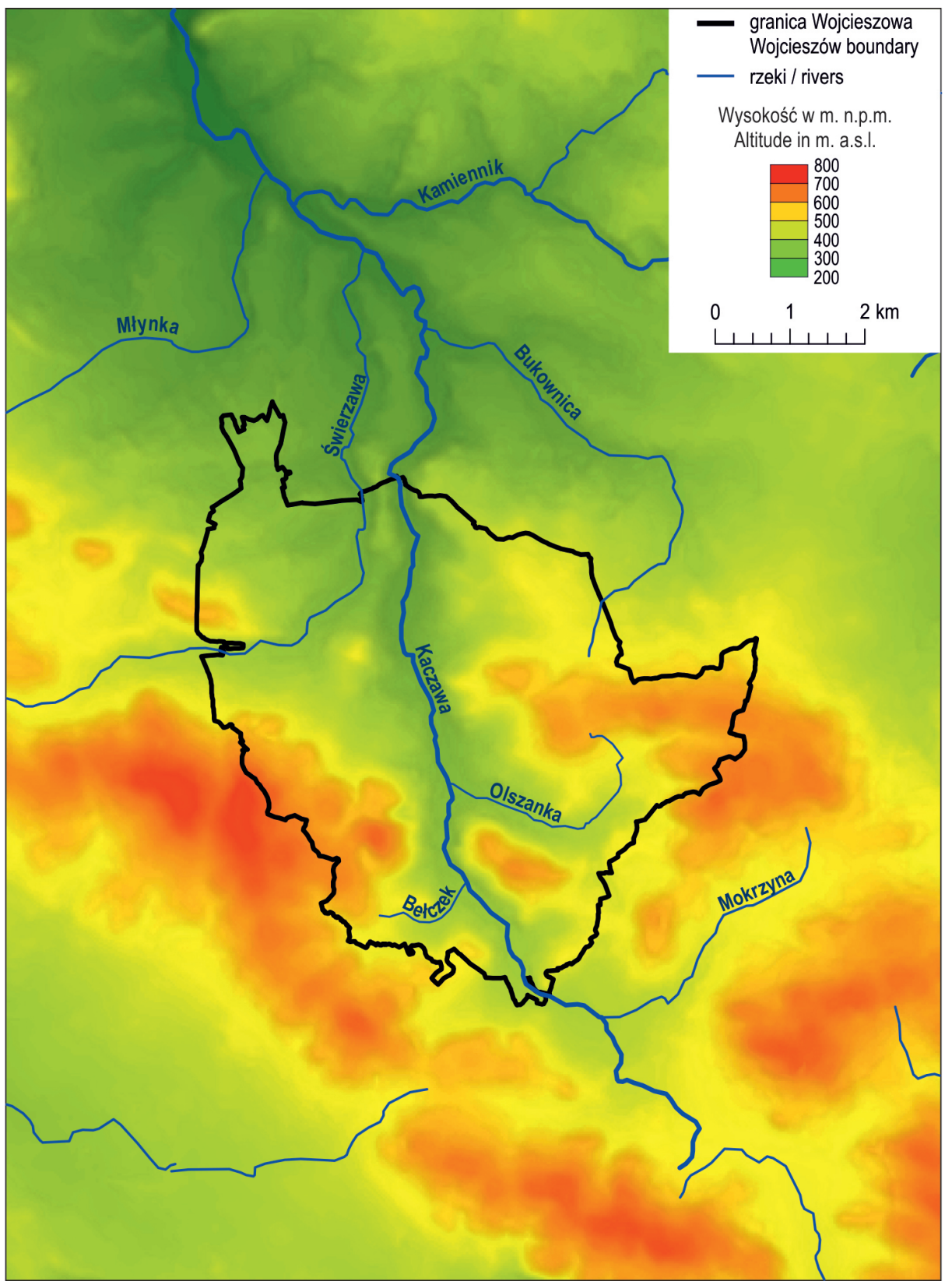

Ryc. 1. Wojcieszów na tle rzeźby terenu i sieci rzecznej

Fig. 1. Land relief and river network in Wojcieszów and its vicinity Źródto: opracowanie własne na postawie danych CODGiK oraz MHPH.

Source: own elaboration based on CODGiK and MHPH data. 


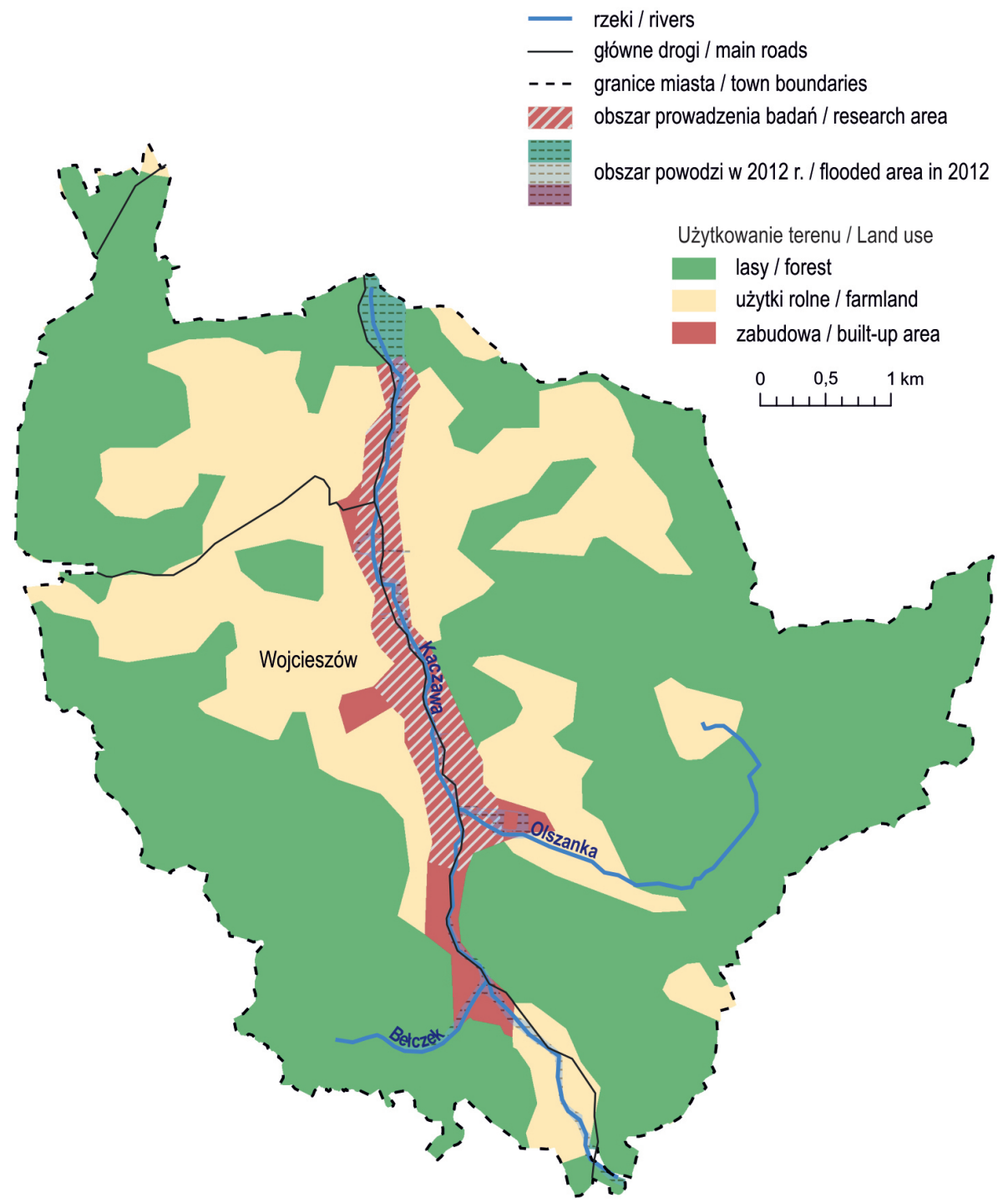

Ryc. 2. Obszar prowadzenia badań społecznych w Wojcieszowie

Fig. 2. Social field work area in Wojcieszów

Źródto: Działek i in. 2017, opracowanie własne na postawie danych CODGiK oraz MHPH.

Source: Działek et al. 2017, own elaboration based on CODGiK and MHPH data. 
Średnia gęstość zaludnienia była nieco niższa do wartości dla całej Polski i wynosiła 117 osób/km², a zatem stosunkowo niska jak na obszar miejski.

Według regionalizacji Kondrackiego (2002) północna część Wojcieszowa leży w mezoregionie Pogórza Kaczawskiego (makroregion Pogórze Zachodniosudeckie), a południowa - w mezoregionie Gór Kaczawskich (makroregion Sudety Zachodnie). Obszar miasta położony jest na wysokości od 314 do $661 \mathrm{~m}$ n.p.m. (średnia wysokość 440 m n.p.m.) (ryc. 1).

Wojcieszów leży w klimatycznym Regionie Dolnośląskim-Zachodnim, gdzie przez niemal 3/4 roku występuje pogoda typu ciepłego, bardzo często zdarzają się dni z zachmurzeniem, a przez prawie pół roku odnotowywane są dni z opadem. Średnia temperatura powietrza wynosi $8^{\circ} \mathrm{C}$, (w styczniu $-3^{\circ} \mathrm{C}$, w lipcu $17^{\circ} \mathrm{C}$ ). Na obszarze miasta notowane są średnie roczne opady o wysokości około $700 \mathrm{~mm}$ (Woś 1999).

Przez Wojcieszów przepływa rzeka Kaczawa, która dzieli go na dwie części: zachodnią i wschodnią. Poniżej miasta w Świerzawie zlokalizowany jest posterunek hydrologiczny zamykający zlewnię górnej Kaczawy o powierzchni 133,7 km². Jednak do granicy miasta w Wojcieszowie Dolnym Kaczawa mierzy 11,6 km długości, a zlewnia obejmuje powierzchnię $51 \mathrm{~km}^{2}$. Średni spadek rzeki na tym odcinku wynosi 15,3\%. W południowej części miasta do Kaczawy uchodzi Olszanka (zwana również Białym Potokiem) (MHPH 2010), dla zlewni której wykonano szczegółowe analizy hydrologiczne. Potok ten ma długość 3,8 km i średni spadek 53,1\%o. Jego zlewnia obejmuje powierzchnię $7,9 \mathrm{~km}^{2}$.

W klasyfikacji funkcjonalnej gmina Wojcieszów została określona jako gmina częściowo zurbanizowana ze znaczącym udziałem obszarów leśnych (Buciak, Pieniążek 2012) (ryc. 2). Poziom bezrobocia, mierzony udziałem osób bezrobotnych w liczbie osób w wieku produkcyjnym, był w 2015 r. wysoki i wynosił 12,9\% (14,2\% w 2014 r.). Charakterystyczny dla miasta jest wysoki odsetek osób korzystających z pomocy społecznej. Odnotowano także stosunkowo niski poziom przedsiębiorczości i aktywności stowarzyszeniowej. Nie zaskakuje zatem obserwowany w ostatnich latach odpływ ludności z miasta. Mimo dosyć niekorzystnej sytuacji społeczno-ekonomicznej dochody własne gminy kształtowały się na poziomie zbliżonym do średniej krajowej i wynosiły w 2014 r. 2160 zł na jednego mieszkańca.

\section{Metody badaweze}

\section{Sytuacja meteorologiczna i hydrologiczna}

Sytuację meteorologiczną na badanym obszarze w okresie bezpośrednio poprzedzającym wystąpienie opadów, które wywołały powódź w dniu 5 lipca 2012 r., oraz w trakcie jej trwania udokumentowano na podstawie map synoptycznych Europy 
na poziomie morza w skali 1: 7500 000, map topografii barycznej, danych radarowych oraz obrazów satelitarnych (METEOSAT). Skorzystano również z depesz synoptycznych ICM. Analizę opadów, które wywołały wezbranie, przeprowadzono na podstawie sum opadów zmierzonych na posterunkach meteorologicznych i opadowych położonych w bezpośrednim sąsiedztwie zlewni (dane z IMGW-PIB: Świerzawa, Kaczorów, Ciechanowice i Bolków). Ponadto do szczegółowej analizy rozmieszczenia opadu, który wystąpił 5 lipca, wykorzystano dane PAC (Precipitation Accumulation) i SRI (Surface Rainfall Intensity) radaru meteorologicznego wykonane w dziesięciominutowych interwałach czasowych.

Sytuacja hydrologiczna została przeanalizowana na podstawie danych z posterunku wodowskazowego IMGW-PIB znajdującego się na Kaczawie w Świerzawie (poniżej Wojcieszowa). Zostały wykorzystane dane dotyczące przepływów dobowych (Q) oraz maksymalnych przepływów rocznych (WQ) za okres 1965-2015. Obliczony również został maksymalny odpływ jednostkowy $q_{\max }$ (Bartnik, Jokiel 2012).

Przepływ maksymalny potoku Olszanka przepływającego przez centrum Wojcieszowa obliczono post factum. Przy ulicy Górniczej w Wojcieszowie wykonano geodezyjnie przekrój, a prędkość obliczono według wzoru Manninga (Lambor 1971). Natężenie przepływu maksymalnego obliczono według wzoru:

$$
\mathrm{Q}_{\max }=\mathrm{P} \cdot \mathrm{V}
$$

gdzie:

$\mathrm{Q}_{\max }-$ przepływ maksymalny $\left[\mathrm{m}^{3} \cdot \mathrm{s}^{-1}\right]$

$\mathrm{P}$ - pole powierzchni przekroju poprzecznego koryta $\left[\mathrm{km}^{2}\right]$

$\mathrm{v}$ - średnia prędkość wody $\left[\mathrm{m} \cdot \mathrm{s}^{-1}\right]$

Obliczone przepływy porównano z przepływami charakterystycznymi, obliczonymi zgodnie z zaleceniami IMGW-BIP za pomocą Formuły Opadowej.

\section{Wyznaczenie obszaru zalewu}

Strefę zalewu wód powodziowych odtworzono na podstawie śladów wielkiej wody wykonanych w trakcie pomiarów terenowych z użyciem odbiornika GPS oraz wykorzystując materiały fotograficzne i audiowizualne wykonane podczas powodzi oraz w ciągu kilku dni po jej wystąpieniu. Zebrane materiały uzupełniono o informacje pozyskane w badanych obszarach podczas wywiadów przeprowadzonych z mieszkańcami zalanych miejscowości w 2016 r. W celu prześledzenia morfologii dna doliny skorzystano z danych LiDAR (naloty z okresu kwiecień 2011 - maj 2013) pochodzących z Państwowych Zasobów Geodezyjnych i Kartograficznych (CODGiK). 


\section{Odtworzenie zasięgu powodzi w pamięci mieszkańców}

Informacje na temat zasięgu powodzi w pamięci mieszkańców zostały zgromadzone podczas indywidualnych wywiadów z 19 osobami, przeprowadzonych we wrześniu 2014 r., czyli dwa lata po powodzi. Respondentów dobrano tak, by byli oni zróżnicowani pod względem demograficznym (płci i wieku), doświadczenia powodzi (ucierpieli na skutek powodzi lub znajdowali się poza zasięgiem wód powodziowych) oraz by reprezentowali różne części miasta. Wywiady zostały powtórzone z tymi samymi osobami dwa lata później, tj. we wrześniu 2016 r. (cztery lata po powodzi) zgodę na udział w powtórnym badaniu wyraziło 11 osób. Celem tej części badania było określenie zmian wyobrażeń o zasięgu powodzi wraz z czasem upływającym od zdarzenia. Podczas pierwszego wywiadu działaniom graficznym na przygotowanym podkładzie towarzyszyła rozmowa o przebiegu powodzi, jej źródłach, trwaniu i konsekwencjach.

W części graficznej badania respondenci mieli do dyspozycji wydrukowaną w skali 1: 6000 barwną ortofotomapę pozyskaną z serwisu Geoportal2, która umożliwiała im rozpoznanie zabudowy. Na mapie tej każdy badany mógł z łatwością zlokalizować własny dom, ważne punkty orientacyjne, najczęściej odwiedzane miejsca we wsi, a na koniec, w towarzystwie prowadzącego badanie, zaznaczyć obszar, który uważa za zalany przez wody powodziowe w 2012 r.

Zebrane informacje przestrzenne poddano obróbce z wykorzystaniem narzędzi GIS. Najpierw zdigitalizowane zostały analogowe dane dotyczące miejsca zamieszkania, aktywności przestrzennej respondentów oraz zasięgu powodzi do formatu wektorowego. Dane liniowe i poligonowe wektoryzowano z dokładnością $1 \mathrm{~m}$ na obszarach, gdzie w terenie widoczne są punkty orientacyjne oraz $3 \mathrm{~m}$ na pozostałych obszarach. Obszarom, które respondenci wskazali jako zalane wodami powodziowymi, przypisano wartość 1, pozostałym natomiast 0 (Brennan-Horley 2010). Zabieg ten umożliwił późniejsze działania z wykorzystaniem algebry map. W kolejnym kroku wykonano konwersję danych wektorowych ilustrujących zasięg powodzi do formatu rastrowego (rozmiar piksela: 1 x $1 \mathrm{~m}$ ). Ostatnim elementem przekształceń było dodawanie powstałych wcześniej rastrowych map zasięgu powodzi. Dzięki temu otrzymano mapy wynikowe przedstawiające, ile razy poszczególne fragmenty miejscowości wskazywane były przez mieszkańców jako pokryte wodą w trakcie powodzi.

\section{Analiza materiałów filmowych o powodzi na portalu YouTube}

Dodatkowy materiał analityczny dostarczył serwis You Tube. Celem tej części badania było określenie, w jaki sposób powódź przedstawiana jest w materiałach tworzonych i udostępnianych przez użytkowników internetu, i jak mogą one wpływać na 
wyobrażenia o przebiegu tego zdarzenia i pamięć społeczną o nim. Analizie poddano dostępne w serwisie filmy na temat powodzi w Wojcieszowie w 2012 r., zgodnie z metodologią prowadzenia tego rodzaju badań (Grzeszna 2017). Doboru materiałów dokonano przy użyciu wewnętrznej wyszukiwarki portalu You Tube, wykorzystując za pierwszym razem filtr trafności, a za drugim razem filtr liczby wyświetleń. Za każdym razem brano pod uwagę pierwszych 20 filmów, gdyż to do nich zwykle najczęściej sięgają użytkownicy serwisu. Spośród nich wybrano te, które rzeczywiście dotyczyły analizowanej powodzi w Wojcieszowie - ostatecznie wybrano 13 materiałów filmowych, które zostały poddane ilościowo-jakościowej analizie zawartości przy użyciu opracowanego wcześniej klucza kategoryzacyjnego. Pod uwagę brano informacje o dacie dodania materiałów, długości trwania filmów, liczby wyświetleń, rozkładu liczby wyświetleń w czasie, zawartości komentarzy pod nagraniami, nadawcy materiału oraz charakterystyki obrazu ukazanego w filmach, wypowiedzi ludzi widocznych w materiałach, rozpiętości czasowej pokazanych zdarzeń, jakości technicznej oraz formy prezentacji materiału. Wyniki dla Wojcieszowa porównane zostały z dziewięcioma innymi obszarami z Polski południowej, dla których prowadzono analogiczne analizy (wyniki tej analizy dostępne są w publikacji: Grzeszna 2017) łącznie przeanalizowano 145 materiałów filmowych z serwisu You'Tube pochodzące z 10 obszarów, w których wystąpiła powódź.

\section{Przebieg powodzi}

\section{Meteorologiczne przyczyny powodzi}

Na początku lipca 2012 r. nad Europą utworzyły się dwa główne ośrodki baryczne. Nad południowo-wschodnią Europą rozbudował się rozległy ośrodek wyżowy, rozciągający się od Morza Śródziemnego przez wschodnią Europę po Morze Białe, natomiast nad północnym Atlantykiem rozbudował się ośrodek niżowy sięgający zatoką od wyspy Jan Mayen na północy po Gibraltar na południu. Taki układ baryczny spowodował uformowanie się falującego, chłodnego frontu atmosferycznego, oddzielającego gorące powietrze napływające po jego wschodniej stronie od znacznie chłodniejszego powietrza polarnego znajdującego się po stronie zachodniej. W konsekwencji z południa następował napływ gorącego powietrza pochodzenia zwrotnikowego pochodzącego z rejonu Morza Śródziemnego i północnej Afryki. Różnica temperatury powietrza po obu stronach frontu dochodziła do kilkunastu stopni Celsjusza. Front ten ulegał zafalowaniu, tworząc wewnątrz niewielkie fale frontalne. Następowało zaciąganie gorącego powietrza od południa i chłodnego z północnego zachodu, co spowodowało szybkie uformowanie młodego niżu, przemieszczającego się wzdłuż frontu (Klejnowski 2012a, b; Olędzki 2012a, b). 

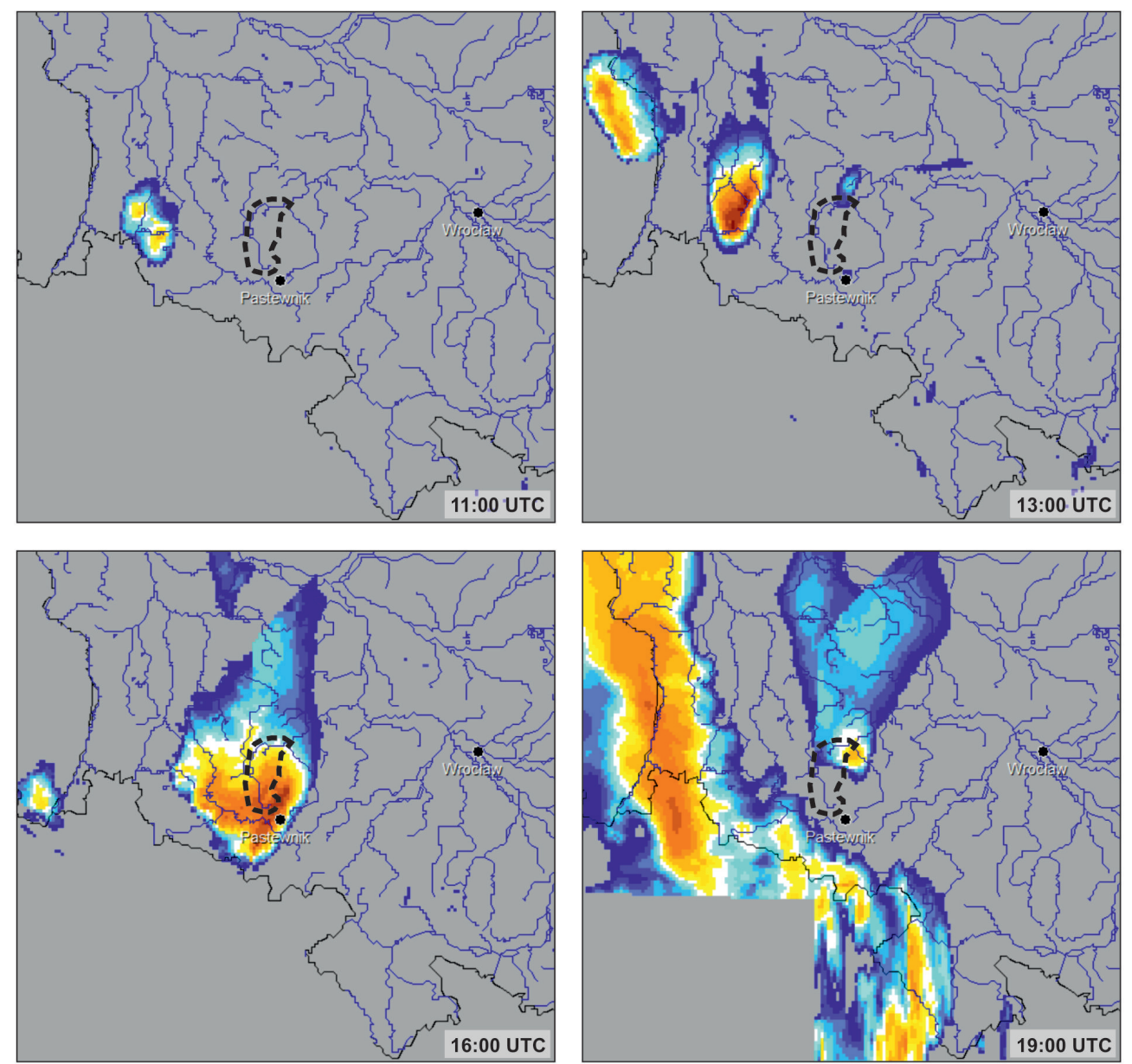

$<0,2$

$0,2-0,5$

$12-20$

0,5-1

$1-1,5$

$1,5-3$

50-80

$3-5$

$>80 \quad[\mathrm{~mm}]$

zlewnia górnej Kaczawy upper Kaczawa catchment

Ryc. 3. Obraz rozkładu godzinnych sum opadów na danych radarowych 5 lipca 2012 r.

Fig. 3. Radar data of hourly precipitation sums on July 5th, 2012

Uwagi: opracowano na podstawie danych godzinnych sum opadów PAC.

Notes: based on PAC data on hourly precipitation sums.

Źródto: Działek i in. 2017, opracowanie własne na podstawie map IMGW-PIB.

Source: Działek et al. 2017, own elaboration based on IMGW-PIB maps. 


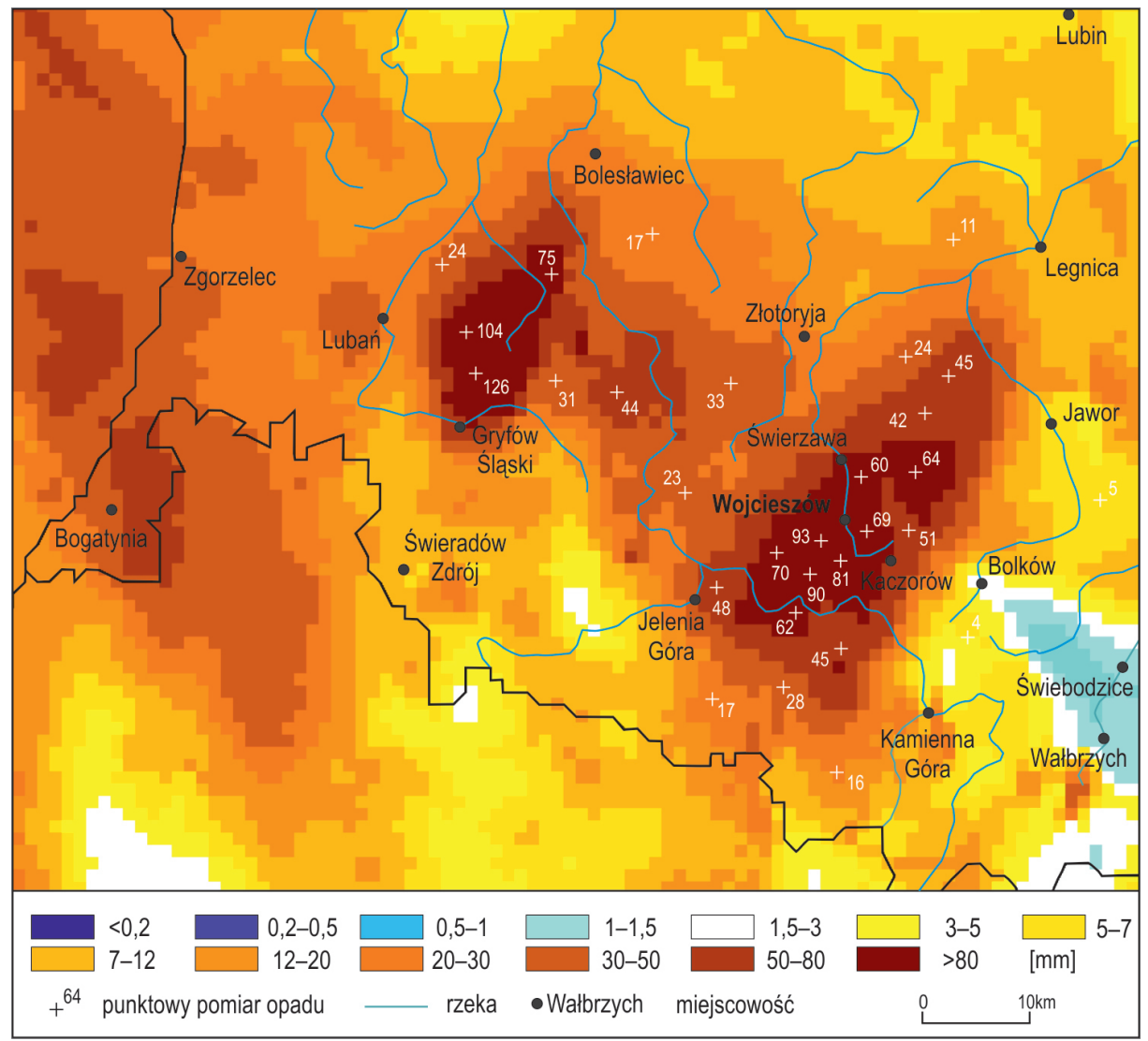

Ryc. 5. Obraz rozkładu dobowych sum opadów na danych radarowych 5 lipca 2012 r.

Fig. 5. Radar data of daily precipitation sums on July 5, 2012

Uwagi: opracowano na podstawie danych godzinnych sum opadów PAC.

Notes: based on PAC data on hourly precipitation sums.

Źródto: opracowanie własne na podstawie map IMGW-PIB.

Source: own elaboration based on IMGW-PIB maps. 
Kontrast termiczny oraz wilgoć napływająca znad wschodniej części Morza Śródziemnego napędzała występowanie zjawisk konwekcyjnych w strefie frontowej. $\mathrm{W}$ obrębie frontu tworzyły się mocno rozbudowane chmury kłębiaste, $\mathrm{z}$ intensywnymi opadami deszczu i burzami z gradem. Z kolei przed linią frontu w odległości ok. 250-300 km, tworzyła się tzw. linia szkwałów. Była to strefa o szerokości kilkudziesięciu kilometrów, w której konwergencja była większa niż w strefie frontu. Występowały tam burze o znacznie większej intensywności niż występujące w strefie frontowej. Tego typu komórki burzowe rozwijały się 5 lipca na obszarze Sudetów i Przedgórza Sudeckiego (ryc. 3; Klejnowski 2012a, b). Jedna z nich zaczęła tworzyć się o godz. 12:00 w okolicy Świeradowa-Zdroju, a następnie w ciągu półtorej godziny, silnie się rozbudowując, przemieszczała się na wschód. O 15:00 w okolicy Kowar zaczęła się tworzyć druga komórka, która powoli przesuwała się ku północy. Około 16:00 obie komórki spotkały się nad zlewnią górnej Kaczawy. Spowodowało to spowolnienie ich przemieszczania się i wzrost sum opadów na tym obszarze. Około 17:40 komórki zaczęły się od siebie oddalać, następnie jednak się połączyły i stopniowo wygasając, przemieściły się na północ, zanikając między Złotoryją a Legnicą. Opady nad zlewnią górnej Kaczawy występowały do 19:50, ale od południowego zachodu przemieszczał się front, w obrębie którego intensywne opady ponownie wystąpiły w zlewni od 21:00. Opady te trwały przez godzinę.

Wysokie sumy opadów występowały w sąsiedztwie badanego obszaru już w dniu poprzedzającym wystąpienie powodzi (ryc. 4). W dniu 4 lipca najwyższe sumy opadów odnotowano w Ciechanowicach (52,6 mm), a 5 lipca - w Kaczorowie (59,2 mm opadu) i w Świerzawie $(48,0 \mathrm{~mm})$. Na pozostałych stacjach, które znalazły się poza obszarem występowania najwyższych opadów, wartości te były już znacznie niższe (22,7 $\mathrm{mm}$ w Ciechanowicach i 5,1 $\mathrm{mm}$ w Bolkowie). Najwyższe sumy opadowe odnotowano w wąskim pasie o długości $25 \mathrm{~km}$ i szerokości 10-12 km, rozciągającym się od wsi Muchów na północnym wschodzie po Jelenią Górę na południowym zachodzie (ryc. 5). Dobowe sumy opadów wyniosły na całym tym obszarze powyżej $60 \mathrm{~mm}$. W północnej części tego obszaru sumy opadów dochodziły do $72 \mathrm{~mm}$, dobowe zaś sumy o wartości 80-90 mm wystąpiły w wąskim pasie o długości $8 \mathrm{~km}$ i szerokości $3 \mathrm{~km}$ mieszczącym się w obrębie wzniesień rozciągających się między górą Skopiec wznoszącą się nad Wojcieszowem a wsią Janowice Wielkie w dolinie Bobru. Maksymalne sumy opadów wyniosły tam $94 \mathrm{~mm}$. Drugie centrum opadowe znajdowało się ok. $40 \mathrm{~km}$ na północny zachód od Wojcieszowa między Lwówkiem Śląskim a Gryfem Śląskim, gdzie sumy opadów przekroczyły $100 \mathrm{~mm}$, a maksymalne wyniosły 127 mm (Franczak, Działek 2017).

Intensywne opady w zlewni górnej Kaczawy rozpoczęły się 5 lipca 2012 r. ok. 14:40 w południowo-zachodniej części zlewni. W ciągu pierwszej godziny sumy opadów wynosiły 10-20 mm. O 16:00 opad z ostatniej godziny w zlewni Bełczku wyniósł maksymalnie $61 \mathrm{~mm}$. Przemieszczająca się na wschód komórka burzowa 


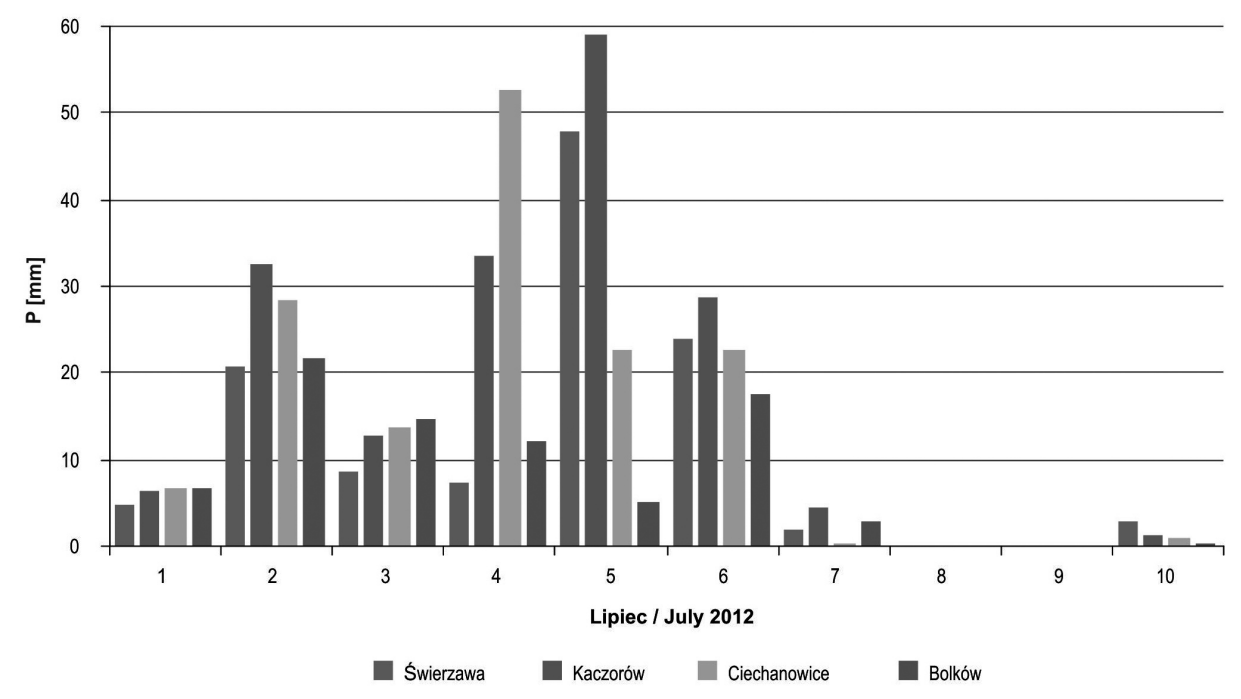

Ryc. 4. Dobowe sumy opadów atmosferycznych w zlewni górnej Kaczawy i w jej sąsiedztwie w okresie 1-10 lipca 2012 r.

Fig. 4. Daily precipitation sums in the upper Kaczawa catchment area and its vicinity between July 1st and 10th, 2012

Źródto: opracowanie własne na podstawie danych z IMGW-PIB.

Source: own elaboration based on IMGW-PIB data.

po dziesięciu minutach objęła swym zasięgiem także zlewnię Olszanki, w której maksymalne natężenie opadu wynosiło $53 \mathrm{~mm} \cdot \mathrm{h}^{-1}$. W tej części zlewni maksymalny opad wystąpił między 15:40 a 16:40, gdy maksymalna suma opadu wyniosła $69 \mathrm{~mm}$. O 17:00 komórka burzowa obejmowała już głównie źródłowy obszar Kaczawy, gdzie natężenie opadu wynosiło $40 \mathrm{~mm} \cdot \mathrm{h}^{-1}$, i stopniowo zaczęła opuszczać obszar zlewni.

\section{Przebieg wezbrania}

Na przełomie czerwca i lipca 2012 r. przepływ Kaczawy w Świerzawie wynosił ok. $0,7 \mathrm{~m}^{3} \cdot \mathrm{s}^{-1}$. Opady burzowe, które występowały w pierwszych dniach lipca, spowodowały wzrost jej przepływu w godzinach porannych 5 lipca do niemal $20 \mathrm{~m}^{3} \cdot \mathrm{s}^{-1}$. Gwałtowny wzrost przepływu Kaczawy oraz jej dopływów wystąpił w godzinach popołudniowych, a przepływ podczas kulminacji fali powodziowej na Kaczawie wyniósł w Świerzawie $115 \mathrm{~m}^{3} \cdot \mathrm{s}^{-1}$. Dla porównania przepływy o różnym prawdopodobieństwie wystąpienia przedstawiono $\mathrm{w}$ tab. 1. 
Spośród dopływów Kaczawy w obrębie Wojcieszowa najintensywniej wezbrały potoki Bełczek i Olszanka. Fala powodziowa w górnym biegu Kaczawy została spłaszczona przez suchy zbiornik (Jezioro Kaczorowskie) mieszczący się w zwężeniu doliny Kaczawy na granicy Wojcieszowa i wsi Kaczorów. Pomimo tego zalane zostało dno doliny i podtopione zostały zabudowania mieszczące się w Wojcieszowie Górnym. Znacznie gwałtowniejszy przebieg wezbrania wystąpił na potoku Bełczek (lewobrzeżny dopływ Kaczawy). Wezbrane wody tego potoku zalały kilkanaście zabudowań mieszczących się wzdłuż ulicy
Tab. 1. Przepływ (Q) i odpływ jednostkowy (q) o danym prawdopodobieństwie wystąpienia Kaczawy w Świerzawie

Table 1. The flow $(Q)$ and specific discharge (q) with a given probability of occurrence in the Kaczawa catchment area in Świerzawa

\begin{tabular}{|c|c|c|}
\hline $\begin{array}{c}\text { Prawdopodobieństwo } \\
\text { Probability }\end{array}$ & $Q\left(\mathrm{~m}^{3} \cdot \mathrm{s}^{-1}\right)$ & $\mathrm{q}\left(\mathrm{m}^{3} \cdot \mathrm{s}^{-1} \cdot \mathrm{km}^{2}\right)$ \\
\hline $50 \%$ & 14,88 & 0,111 \\
\hline $10 \%$ & 52,97 & 0,396 \\
\hline $5 \%$ & 71,27 & 0,533 \\
\hline $2 \%$ & 95,37 & 0,713 \\
\hline $1 \%$ & 113,23 & 0,847 \\
\hline $0,5 \%$ & 130,94 & 0,979 \\
\hline $0,1 \%$ & 172,00 & 1,271 \\
\hline
\end{tabular}

Miedzianej, a następnie spowodowały całkowite wypełnienie koryta Kaczawy i zalanie drogi wojewódzkiej nr 328. Z kolei centrum miasta zostało zalane przez prawobrzeżny dopływ Kaczawy, potok Olszanka. Obliczony przepływ maksymalny w przekroju pomiarowym zlokalizowany w zwężeniu dna doliny powyżej zabudowań wyniósł $15,5 \mathrm{~m}^{3} \cdot \mathrm{s}^{-1}$. Połączenie fal powodziowych Kaczawy i jej dopływów spowodowało utworzenie się rozległego rozlewiska w obrębie dna doliny w Wojcieszowie Dolnym, którego szerokość dochodziła do $150 \mathrm{~m}$.

\section{Pamięć społeczna o powodzi w Wojcieszowie}

Podczas wywiadów prowadzonych dwa lata po wystąpieniu powodzi (wrzesień 2014) okazało się, że już wtedy wielu mieszkańców miało duże trudności z podaniem daty jej wystąpienia. Wśród przewijających się określeń najczęściej pojawiał się „początek wakacji” 2012 r. W pamięci mieszkańców Wojcieszowa zachował się jednak gwałtowny przebieg tej powodzi. Wspominali oni, że w okresie poprzedzającym jej wystąpienie mocno padało, pojawiały się nawracające ulewy, następnie woda zaczęła spływać z otaczających gór i podnosił się jej poziom w rzece, co było ich zdaniem bardzo niespodziewane. Inne badania wskazują, że niejednokrotnie taka reakcja na zdarzenie, poczucie zaskoczenia jego wystąpieniem, przekładające się na podkreślanie jego rzadkości i ekstremalności, wynika z niskiego poziomu przygotowania do niego (Krasovskaia i in. 2001; Kuhlicke 2010; Wachinger, Renn 2010). 
Powódź odczuły nie tylko osoby, których dobytek bezpośrednio ucierpiał na skutek zdarzenia, ale również pozostali mieszkańcy miasta i okolicy, których normalne funkcjonowanie zostało przerwane przez zalanie głównej drogi przebiegającej przez rozciągnięty południkowo Wojcieszów. Wywołane tym uciążliwości spowodowały, że „zalana ulica” była jednym z najczęściej pojawiających się w wypowiedziach mieszkańców słów, obok „ulewy”, „gór” i „rzeki”. Nieco rzadziej wskazywali również na murki, które stanowią część ocembrowania rzeki, most, który uległ uszkodzeniu, oraz najczęstsze szkody w gospodarstwach domowych, czyli zalane piwnice.

Zdaniem mieszkańców Wojcieszowa powódź trwała ok. tygodnia, tj. do momentu, kiedy woda wróciła do koryta oraz przywrócono możliwość poruszania się po miejscowości. Zatem w rozumieniu osób, które ucierpiały, powódź to nie tylko sam moment wezbrania i zniszczeń, jakich dokonują wody powodziowe, ale również okres powrotu do względnej normalności, możliwości przystąpienia do usuwania strat i odbudowy zniszczeń. W przypadku powodzi błyskawicznej może on być relatywnie krótki. W prowadzonych równolegle podobnych badaniach w Czarnej w województwie podkarpackim powódź w czerwcu 2009 r. trwała zdaniem poszkodowanych mieszkańców 2-3 dni. W Bieruniu natomiast, gdzie przebieg powodzi w 2010 r. miał zupełnie inny charakter, wody powodziowe przerwały wał przeciwpowodziowy, zalewając domostwa do znacznych wysokości, a wody w rozlewisku za wałami utrzymywały się przez kilka tygodni, wydłużając długość trwania powodzi w odczuciu mieszkańców nawet do dwóch miesięcy (Biernacki, Fiedeń 2017; Franczak, Działek 2017).

Intensywne opady deszczu stanowią dla mieszkańców Wojcieszowa motywację do nasilenia wspomnień oraz wzajemnych rozmów o przeżytej powodzi. Podczas badań mieszkańcy charakteryzowali się ograniczonymi chęciami do dzielenia się wspomnieniami; wynika to prawdopodobnie z gwałtowności zdarzenia i wyrażanego przez nich poczucia nieprzewidywalności takiego zjawiska, co dobrze oddaje wypowiedź jednego z respondentów: „A co tu wspominać, przyszło i poszło, nic tego nie zatrzyma".

Dodatkowym wsparciem w zrozumieniu społecznej pamięci o powodzi służą materiały zgromadzone w mediach społecznościowych, w szczególności w serwisie YouTube, który umożliwia dzielenie się różnego rodzaju nagraniami, wśród których znajdują się również te dokumentujące klęski żywiołowe. Tego rodzaju materiały stanowią swego rodzaju społeczne archiwum pamięci o tych zjawiskach, zwłaszcza w sytuacji gdy są one tworzone i umieszczane przez bezpośrednich obserwatorów zjawiska. Wraz z upływem czasu od zdarzenia mogą one mieć coraz większe znaczenie w kształtowaniu wyobrażeń o nim.

Obraz powodzi przedstawionej w materiałach z Wojcieszowa nie odbiega treścią od tego, co przedstawiają filmy z innych obszarów, dla których prowadzono analizy (Grzeszna 2017) bez względu na to, czy miały one charakter powodzi błyskawicznej, 


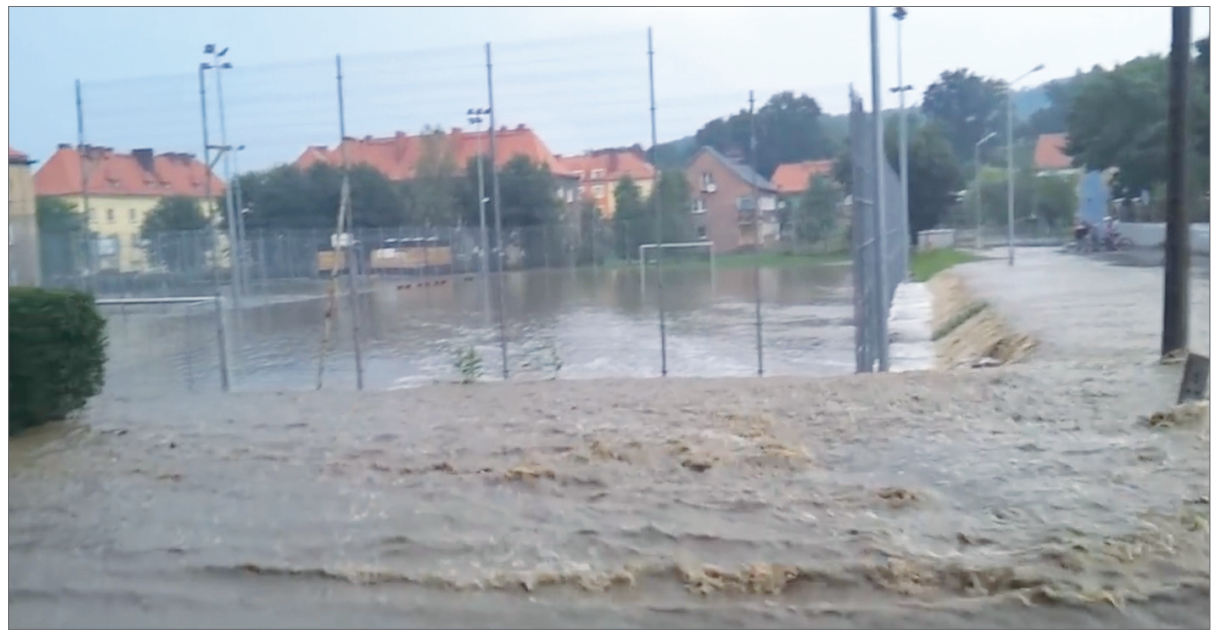

Ryc. 6. Kadr z nagrania przedstawiającego powódź w Wojcieszowie w okolicach ulicy Górniczej Fig. 6. Film frame from the Wojcieszów flood recorded in the vicinity of Górnicza Street Źródto: Mariusz Bąk, wykorzystano za zgodą autora.

Source: Mariusz Bąk, used with permission.

Ryc. 9. Zasięgi powodzi wskazywane przez mieszkańców Wojcieszowa w 2014 r.

Fig. 9. Areas covered by flood water marked by Wojcieszów inhabitants in 2014

Źródto: Działek i in. 2017, badania własne przedstawione na ortofotomapie-Geoportal2. Source: Działek et al. 2017, own study shown on the Geoportal2 orthophotomap.

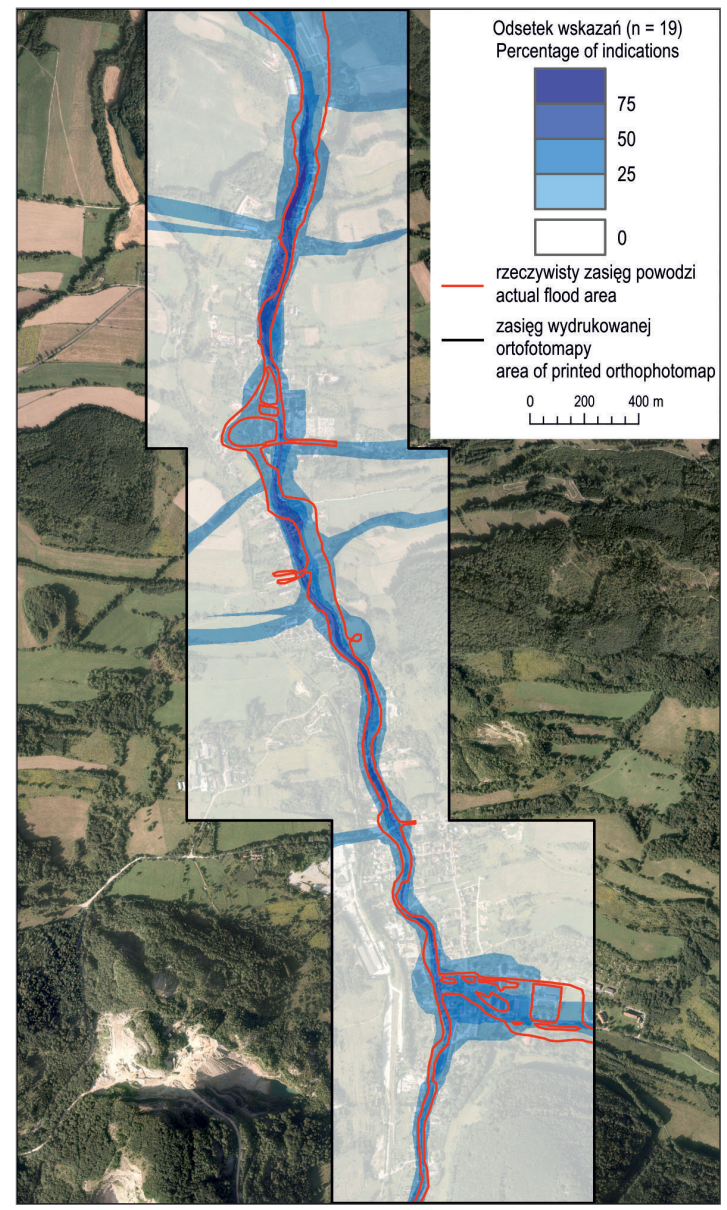


czy były skutkiem przerwania wałów. Filmy pokazują zatem głównie zalane ulice, podtopione gospodarstwa domowe oraz uszkodzoną infrastrukturę drogową (ryc. 6). W dwóch nagraniach widoczna jest akcja straży pożarnej.

Co ciekawe, wszystkie materiały o powodzi w Wojcieszowie zostały zamieszczone przez nadawców należących do grupy User Generated Content (UGC), czyli zwykłych użytkowników internetu, którzy nie tworzą w sposób profesjonalny materiałów dziennikarskich czy filmowych (Cha i in. 2007; Simonsen 2011). Żaden z przeanalizowanych materiałów z Wojcieszowa nie pochodził od innych możliwych grup nadawców, czyli mediów, służb ratowniczych, jednostek samorządowych czy organizacji pozarządowych. W całej analizowanej próbie filmy takie stanowiły co piąty materiał.

Należy zwrócić uwagę, że nagrania obrazujące powódź w Wojcieszowie zostały umieszczone w sieci wyjątkowo szybko od momentu wystąpienia zjawiska, zdecydowana bowiem większość pojawiła się nie później niż tydzień po powodzi. Materiały te spotkały się jednak z niewielkim, w porównaniu z innymi analizowanymi obszarami, zainteresowaniem. Średnio film z Wojcieszowa obejrzano ok. 3,6 tys. razy, podczas gdy wartość średniej liczby wyświetleń dla materiałów z zalanych osiedli Tarnobrzega, Bierunia czy Tuchowa, jest trzykrotnie wyższa.

Na szczególną uwagę zasługuje także rozkład wyświetleń filmów w czasie. Podczas analizy materiałów filmowych z innych miejscowości (Grzeszna 2017) wykazano, że odbiorcy niektórych materiałów mają tendencję (często jednak malejącą z upływem czasu) do powracania do nagrań albo regularnie w okolicach rocznicy wystąpienia powodzi, albo w okresie potencjalnego lub realnego zagrożenia powodzią, np. nasilonych opadów czy ogłoszenia pogotowia przeciwpowodziowego (ryc. 7). Tendencję taką zaobserwowano w odniesieniu do co piątego filmu z całej próby poddanej analizie. Niestety dane dostępne w serwisie nie pozwalają stwierdzić, czy odbiorcami treści są mieszkańcy zalanych miejscowości, czy osoby z innych części kraju, co może mieć miejsce w przypadku powodzi szeroko przedstawianych w mediach, takich jak np. powódź w Bogatyni w 2010 r. Niemniej jednak w przypadku materiałów ilustrujących przebieg powodzi w Wojcieszowie takiego trendu nie odnotowano. Statystyki wszystkich filmów z tej miejscowości pokazują, że materiały były odwiedzane przez internautów tylko tuż po umieszczeniu ich na portalu YouTube, czyli w okresie wystąpienia powodzi, i tuż po jej zakończeniu (ryc. 8).

Analiza zmienności liczby wyświetleń oraz zawartości materiałów o powodziach, które nawiedziły różne miejscowości w Polsce południowej, zamieszczonych na portalu YouTube pokazują, że powódź w Wojcieszowie w 2012 r. potraktowana została przez mieszkańców jako intensywne, ale krótkotrwałe zjawisko, które nie pozostało „żywe” w ich pamięci. Stosunkowo niewysokie zainteresowanie odbiorców materiałami oraz brak wyświetleń filmów w późniejszym okresie mogą świadczyć, 


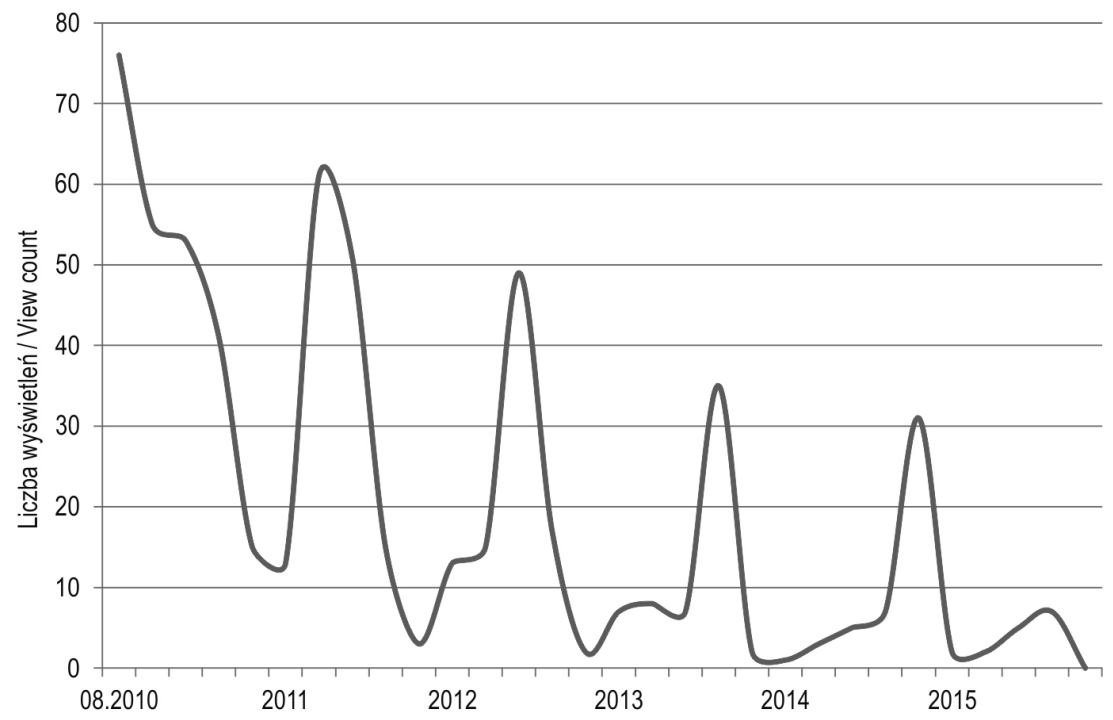

Ryc. 7. Przykład materiału filmowego o powodzi z cyklicznością wyświetleń w czasie

Fig. 7. Example of flood recording with cyclic view count

Źródto: Działek i in. 2017, opracowanie własne na podstawie danych o liczbie wyświetleń dla filmu „Bogatynia, powódź ul. Kościuszki”, https://www.youtube.com/watch?v-vQ6S6IheTeY (11.03.2017).

Source: Działek et al. 2017, own elaboration based on view count of video „Bogatynia, powódź ul. Kościuszki”, https://www.youtube.com/watch?v=vQ6S6IheTeY (11.03.2017).

że powódź w Wojcieszowie nie wpisała się pamięć lokalnej społeczności i uległa szybkiemu zapomnieniu, co być może związane jest właśnie z gwałtownym charakterem tej powodzi.

Pojęcie mieszkańców Wojcieszowa o zasięgu wód powodziowych jest nieprecyzyjne, istnieje także wyraźnie zróżnicowanie wśród badanych osób (ryc. 9, 10) (Biernacki, Fiedeń 2017). Jedynymi zalanymi miejscami wskazywanymi przez niemal wszystkich respondentów są fragmenty miasta położone w najbliższej okolicy koryta Kaczawy. Istotne jest jednak, że dla każdego pytanego mieszkańca, koryto Kaczawy ma inne granice - czasami kończy się na granicy przeciętnego zasięgu wody, innym razem na betonowym obrzeżu koryta (wspomniane wcześniej murki), a niejednokrotnie również na przebiegających w okolicy rzeki ulicach.

Wyobrażenia na temat zasięgu powodzi, a co za tym idzie, pamięć o przestrzennej skali tego wydarzenia, jest wśród mieszkańców Wojcieszowa silnie uzależniona od miejsca zamieszkania. Okazuje się, że niektóre wystąpienia wody z koryta rzeki 


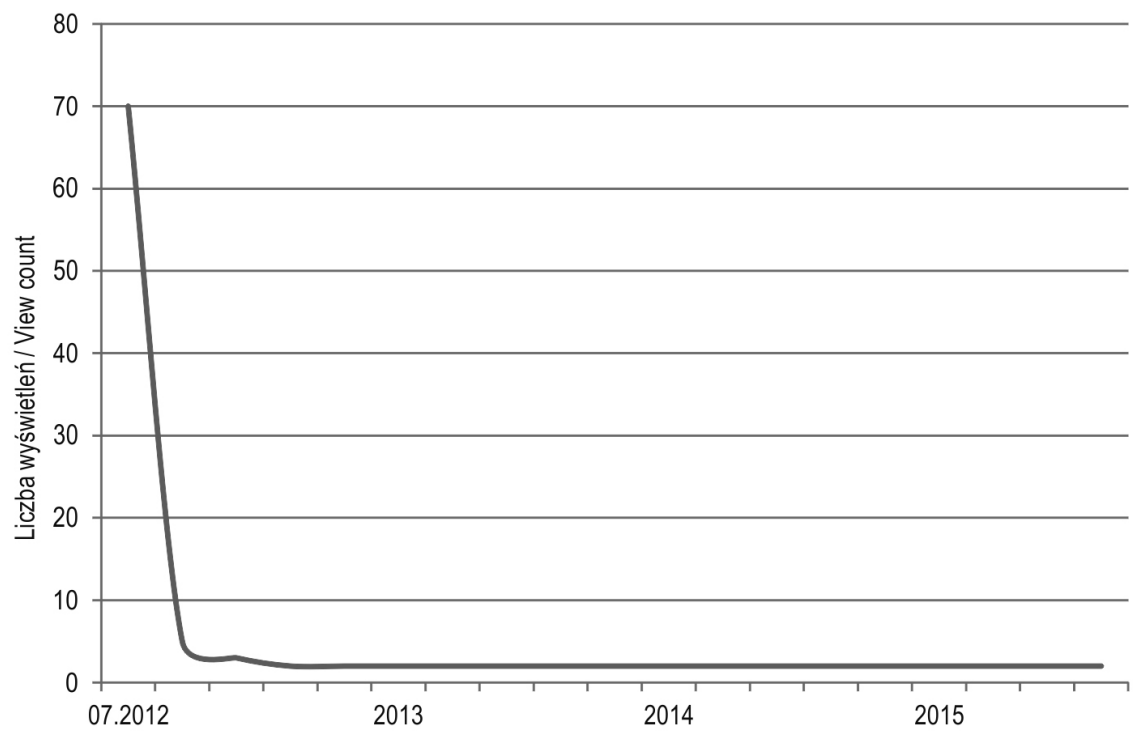

Ryc. 8. Przykład wyświetleń w czasie materiału filmowego o powodzi w Wojcieszowie Fig. 8. Example of view count of the Wojcieszów flood recording

Źródto: opracowanie własne na podstawie danych o liczbie wyświetleń dla filmu „Powódź, Wojcieszów 2012.07.05", https://www.youtube.com/watch?v-NnvH-4FgMP4 (30.04.2017).

Source: own elaboration based on view count of video filmu „Powódź, Wojcieszów 2012.07.05”, https:// www.youtube.com/watch?v=NnvH-4FgMP4 (30.04.2017).

wskazywały wyłącznie osoby mieszkające w bliskim sąsiedztwie tych miejsc. Ponadto żaden z dziewięciu respondentów (podczas pierwszej tury badań w 2014 r.) mieszkających w północnej części miasta nie wskazał jako zalanego obszaru zabudowań szkoły na południu miasta. Mieszkańcy z części południowej natomiast dość precyzyjnie wskazali obszary okolicy swego miejsca zamieszkania, ale powiększali obszar zalewu w miejscach bardziej oddalonych. W związku z powyższym nie dziwi, że wobec mniejszej precyzji wskazań respondenci zazwyczaj wskazywali obszary mniejsze od tych, które faktycznie zostały zalane wodą (ryc. 9). Ograniczenie wyobrażeń o przebiegu powodzi do najbliższej okolicy, przekładające się na postrzeganie zagrożenia, wskazywane było również w badania prowadzonych w Słowenii (Brilly, Polic 2005).

Na mapach wyobrażeniowych uwidacznia się również kluczowa dla funkcjonowania lokalnej społeczności ulica przecinająca miasto z północy na południe, którą wskazywano wielokrotnie jako pokrytą wodą bez względu na miejsce zamieszkania 
respondentów. Część z nich, pomimo miejsca zamieszkania dającego możliwość obserwowania w trakcie powodzi i następnie bardziej precyzyjnego wskazania m.in. potoków spływających z gór, zaznaczała wyłącznie zalane okolice rzeki i ulicy. W ten sposób mieszkańcy zapamiętali obszary dla nich istotne, można powiedzieć strategiczne, a nie przyjęli do wiadomości albo zapomnieli o innych miejscach. Na to zjawisko bez wątpienia wpływ mógł mieć gwałtowny przebieg zjawiska typowy dla powodzi błyskawicznej, a co za tym idzie, ograniczony czas na percepcję i zapamiętywanie. Dodatkowo zalana ulica i most stanowią dla mieszkańców ważne punkty orientacyjne, stąd też ich zaznaczenie na mapie zalanych obszarów może wynikać z dzielenia się swoimi przeżyciami z innymi mieszkańcami. Wyobrażenia o zasięgu powodzi konstruowane są zatem na podstawie zarówno osobistych doświadczeń, jak
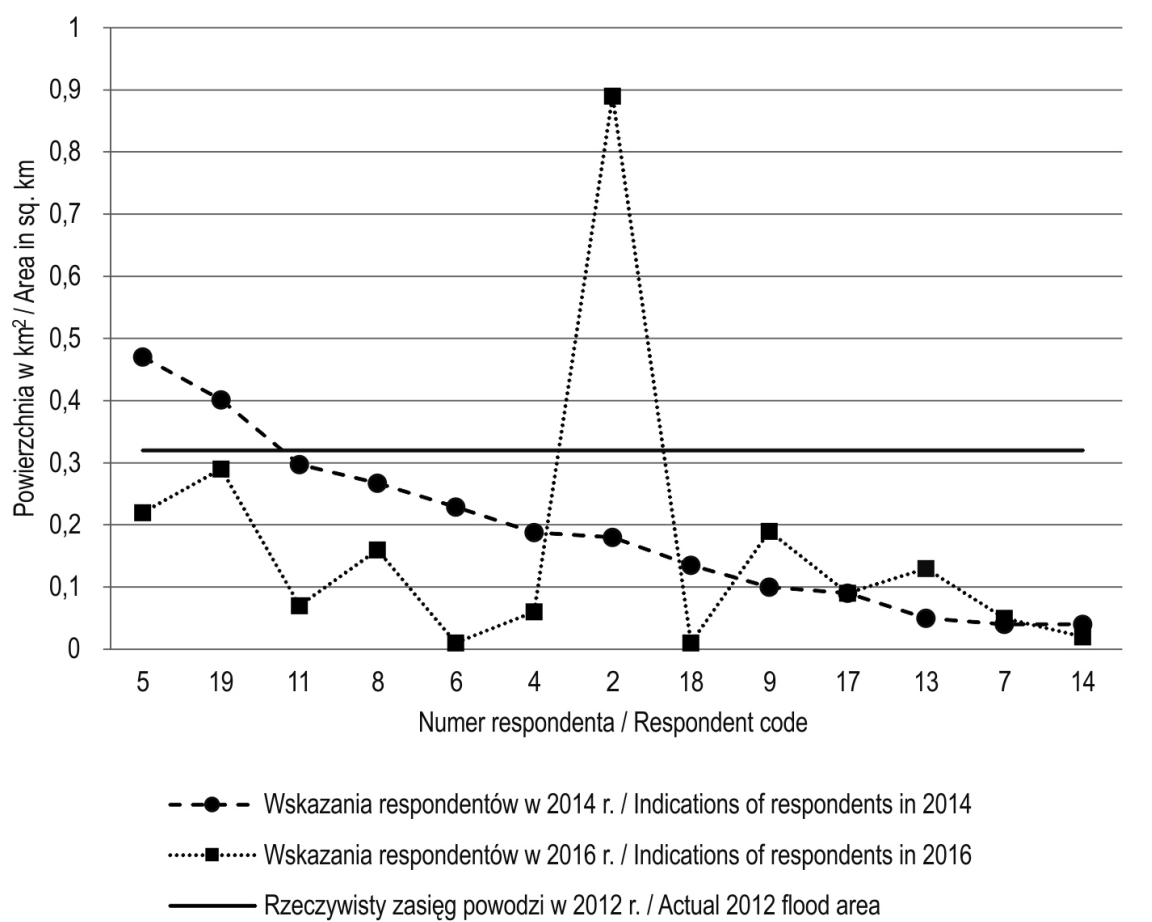

Ryc. 10. Powierzchnia obszaru powodzi wskazywana przez respondentów w 2014 i 2016 r. w porównaniu z rzeczywistą powierzchnią obszaru powodzi w Wojcieszowie w 2012 r.

Fig. 10. Areas covered by flood water marked by inhabitants in 2014 and 2016 compared with actual 2012 flood area in Wojcieszów 
i przekazów innych osób, podlegając jednak modyfikacjom wynikającym ze specyfiki procesów poznawczych człowieka.

Średnia wielkość wskazywanego przez respondentów obszaru zalanego w trakcie powodzi w 2012 r. podczas badania w 2014 i 2016 r. jest bardzo zbliżona. $\mathrm{Na}$ tę wartość wpływ miała jednak odpowiedź jednej osoby, która wskazała obszar znacząco większy niż w pierwszej turze badania (tego respondenta wyłączono z dalszych analiz). Spośród pozostałych respondentów trzy osoby wskazały obszar nieco większy niż podczas pierwszego badania, jedna o zbliżonej powierzchni, pozostałe sześć natomiast wskazały po dwóch latach mniejszy obszar (ryc. 10). Tendencja do zmniejszania postrzeganego zasięgu powodzi dotyczyła w szczególności osób, które w trakcie pierwszej tury badania w dwa lata po powodzi zaznaczały obszar najbardziej zbliżony do rzeczywistego obszaru zalania. W przypadku tych dziesięciu respondentów średnia powierzchnia obszaru pokrytego wodami powodziowymi zmniejszyła się w ciągu dwóch lat w pamięci mieszkańców o $44 \%$. Potwierdza to, że obraz powodzi również w wymiarze przestrzennym ulega zatarciu z czasem, a osoby, które były świadkami powodzi, mają tendencję do wskazywania mniejszego niż rzeczywisty zasięgu powodzi. Tendencja ta pogłębia się z upływem czasu od zaistniałej katastrofy, a w przypadku powodzi błyskawicznej w większym tempie. Potwierdzają to przedstawione tutaj wyniki badań z Wojcieszowa, a także podobne badania z Czarnej. Kontrastują one z wynikami badań nad wyobrażeniami zasięgu powodzi w Bieruniu, gdzie zalew wodami powodziowymi trwał dłużej, co wpłynęło na stabilniejszy obraz jego zalewu w pamięci mieszkańców (Biernacki, Fiedeń 2017).

\section{Dyskusja i wnioski}

Powódź w lipcu 2012 r. w Wojcieszowie wywołana została opadem burzowym, który wystąpił w obrębie linii szkwałów przed przemieszczającym się frontem atmosferycznym. Opad ten charakteryzował się bardzo dużym natężeniem, które na badanym obszarze dochodziło do $69 \mathrm{~mm} \cdot \mathrm{h}^{-1}$, a suma opadu przekroczyła $94 \mathrm{~mm}$. Były to wartości podobne jak podczas powodzi błyskawicznych, które występowały w innych zlewniach zarówno w Karpatach (Izmaiłow i in. 2008; Gorczyca, Wrońska-Wałach 2008; Bryndal i in. 2010; Gorczyca i in. 2013; Kowalczuk i in. 2013; Bryndal 2014a, b; Bryndal i in. 2017), jak i w Sudetach (Franczak, Listwan-Franczak 2016).

Fala wezbraniowa na górnym biegu Kaczawy oraz na jej dopływach charakteryzowała się bardzo krótkim czasem koncentracji. Przepływy okołokulminacyjne osiągnięte zostały w ciągu 30-40 min od wystąpienia najintensywniejszych opadów. Odpływ jednostkowy Kaczawy w profilu wodowskazowym w Świerzawie wyniósł $0,86 \mathrm{~m}^{3} \cdot \mathrm{s}^{-1} \cdot \mathrm{km}^{2}$ i nie wyróżniał się na tle odnotowywanych podczas powodzi 
błyskawicznych w innych regionach kraju. Wiele lokalnych zdarzeń w Polsce charakteryzowało się znacznie większym maksymalnym odpływem jednostkowym, co wykazali liczni autorzy (Parczewski 1960; Izmaiłow i in. 2008; Bryndal 2009, 2010, 2011, 2014a, b, 2015; Bryndal i in. 2010, 2017; Bucała, Budek 2011; Ostrowski i in. 2012; Franczak, Listwan-Franczak 2016; Franczak 2016, 2017). Większość spośród tych badań dotyczyła jednak zlewni karpackich, a tylko pojedyncze zlewni sudeckich (tab. 2). Największe wartości odnotowano w znacznie mniejszych zlewniach niż zlewnia Kaczawy, np. niż w profilu wodowskazowym w Świerzawie $(\mathrm{A}=133,7$ km²). Jednak w poszczególnych zlewniach cząstkowych oraz w górnej części badanej zlewni wartości maksymalnego odpływu jednostkowego były znacznie większe od odnotowanych w Świerzawie. Maksymalny odpływ jednostkowy w Dolnym Wojcieszowie wyniósł $1,95 \mathrm{~m}^{3} \cdot \mathrm{s}^{-1} \cdot \mathrm{km}^{2}$, w zlewni Olszynki natomiast $-2,06 \mathrm{~m}^{3} \cdot \mathrm{s}^{-1} \cdot \mathrm{km}^{2}$. Wartości te były podobne jak podczas innych historycznych katastrofalnych powodzi, które odnotowano w dorzeczu Odry. Wielkość kulminacji fali wezbraniowej w lipcu 2012 r. w Świerzawie nie wyróżniała się na tle innych powodzi, które wystąpiły w ciągu ostatniego półwiecza. Przepływ maksymalny $\left(115 \mathrm{~m}^{3} \cdot \mathrm{s}^{-1}\right)$ był podobny do odnotowanego podczas powodzi w 1977 i 2001 r., ale niższy niż podczas powodzi w 1997 r. $\left(Q_{\max }=152 \mathrm{~m}^{3} \cdot \mathrm{s}^{-1}\right)$. Wówczas jednak intensywne opady objęły całą zlewnię, a w 2012 r. jedynie jej część. W Wojcieszowie przepływ kulminacji fali powodziowej był wyższy niż podczas wcześniej wspomnianych powodzi (Franczak, Działek 2017).

Powódź błyskawiczna, która wystąpiła w Wojcieszowie w 2012 r., nie była jedynym tego typu zdarzeniem w historii miasta. Bardzo podobne przyczyny i przebieg miała katastrofalna powódź, która zdarzyła się w XVII w., a dokładniej 2 czerwca 1608 r. Według zapisków kronikarskich powódź miał wywołać gwałtowny opad burzowy, który rozpoczął się ok. 13:00 i po dwóch godzinach osiągnął maksymalne natężenie. Fala powodziowa była jednak znacznie wyższa niż w 2012 r. i straty materialne odnotowano na znacznie większym obszarze, ponieważ w Złotoryi głębokość rozlewiska dochodziła do $1,5 \mathrm{~m}$. W wyniku tej powodzi w Wojcieszowie utonęło 126 osób, co stanowiło ponad 15\% jego ówczesnej liczby mieszkańców (Stockmann 1892; Gorzkowski 2008).

W przywoływanych na prośbę badaczy wspomnieniach powódź w Wojcieszowie z 2012 r. powraca jako gwałtowane i niespodziewane zdarzenie, mimo że w poprzedzającym je dwudziestoleciu doszło do dwóch powodzi o porównywalnej lub większej skali (tab. 3). Być może takie zdarzenia, ze względu na swój charakter, traktowane są jako zdarzenia wyjątkowe, zwłaszcza że w okresie powojennym, od czasu wymiany ludności po II wojnie światowej do tzw. powodzi tysiąclecia w 1997 r., doszło w tej okolicy tylko do jednej poważniejszej powodzi - w 1977 r. Pamięć społeczna o powtarzających się regularnie powodziach sprzed II wojny światowej znikła wraz ze wspomnianą wymianą ludności. Zdarzenie z 2012 r., jak się wydaje, jest traktowane podobnie jak powódź z 1997 r. W tym drugim przypadku dodatkowy wpływ na jej 
Tab. 2. Przepływ maksymalny $\left(Q_{\max }\right)$ i maksymalny odpływ jednostkowy $\left(\mathrm{q}_{\max }\right)$ podczas powodzi błyskawicznych w polskich Karpatach i Sudetach

Table 2. The flood peak $\left(Q_{\max }\right)$ and unit flood peak $\left(\mathrm{q}_{\max }\right)$ for local flash flood events in the Polish Carpathians and Sudetes

\begin{tabular}{|c|c|c|c|c|c|c|c|}
\hline Lp. & $\begin{array}{l}\text { Rzeka } \\
\text { River }\end{array}$ & $\begin{array}{l}\text { Przekrój pomiarowy } \\
\text { Cross section }\end{array}$ & $\begin{array}{c}\mathrm{A} \\
\left(\mathrm{km}^{2}\right)\end{array}$ & $\begin{array}{c}\text { Qmax } \\
\left(\mathrm{m}^{3} \cdot \mathrm{s}^{-1}\right)\end{array}$ & $\begin{array}{c}\text { qmax } \\
\left(\mathrm{m}^{3} \cdot \mathrm{s}^{-1} \cdot \mathrm{km}^{2}\right)\end{array}$ & $\begin{array}{l}\text { Rok } \\
\text { Year }\end{array}$ & $\begin{array}{c}\text { Źródło } \\
\text { Reference }\end{array}$ \\
\hline \multicolumn{8}{|c|}{ Karpaty / Carpathians } \\
\hline 1 & ciek bez nazwy & Pilzno & 7,5 & 35,0 & 4,60 & 2004 & Bryndal (2006) \\
\hline 2 & Rybny Potok & Zawoja & 9,2 & 19,7 & 2,15 & 2014 & Franczak (2016) \\
\hline 3 & Dolżyca & Dolżyca & 9,7 & 42,6 & 4,39 & \multirow{2}{*}{1957} & \multirow{2}{*}{ Cieplowski (1970) } \\
\hline 4 & Osławica & Osławica & 31,1 & 84,5 & 2,71 & & \\
\hline 5 & Kasinczanka & Kasinka Mała & 48,0 & 171,5 & 3,60 & 2014 & Bryndal i in. (2017) \\
\hline 6 & Skawica & Zawoja & 48,6 & 120,0 & 2,47 & 1983 & Franczak (2016) \\
\hline 7 & Cicha Woda & Zakopane & 58,4 & 195,0 & 3,34 & 1968 & \multirow{4}{*}{$\begin{array}{l}\text { Bartnik, Jokiel } \\
\quad(2012)\end{array}$} \\
\hline 8 & Kamionka & Jamnica & 62,5 & 271,0 & 4,34 & . & \\
\hline 9 & Sękówka & Gorlice & 121,2 & 450,0 & 3,71 & . & \\
\hline 10 & Wielki Rogoźnik & Ludźmierz & 124,0 & 336,0 & 2,71 & . & \\
\hline 11 & Skawica & Skawica & 139,0 & 179,0 & 1,29 & 1983 & \multirow{2}{*}{ Franczak (2017) } \\
\hline 12 & Stryszawka & Sucha Beskidzka & 139,7 & 219,0 & 1,57 & 2014 & \\
\hline \multicolumn{8}{|c|}{ Sudety / Sudetes } \\
\hline 13 & Kamienna & Jakuszyce Dolne & 5,8 & 20,9 & 3,60 & \multirow{4}{*}{1997} & $\begin{array}{l}\text { Bartnik, Jokiel } \\
\text { (2012) }\end{array}$ \\
\hline 14 & Olszanka & Wojcieszów & 7,9 & 15,5 & 2,06 & & \multirow{3}{*}{$\begin{array}{c}\text { Dubicki (1999) } \\
\text { Franczak, Listwan- } \\
\text {-Franczak (2016) }\end{array}$} \\
\hline 15 & Olza & Istebna & 34,8 & 63,5 & 1,83 & & \\
\hline 16 & Wilczy Potok & Wilkanów & 35,0 & 150,0 & 4,25 & & \\
\hline 17 & Nysa Kłodzka & Międzylesie & 49,7 & 86,7 & 1,74 & 1997 & \multirow{4}{*}{$\begin{array}{c}\text { Dubicki (1999) } \\
\text { Franczak, Listwan- } \\
\text {-Franczak (2016) }\end{array}$} \\
\hline 18 & Miedzianka & Bogatynia & 58,9 & 185,0 & 3,15 & 2010 & \\
\hline 19 & Biała Głuchołaska & Jesenik & 116,9 & 220,0 & 1,88 & \multirow{2}{*}{1997} & \\
\hline 20 & Bystrzyca & Jugowice & 123,0 & 294,0 & 2,39 & & \\
\hline \multirow{2}{*}{21} & \multirow{2}{*}{ Kaczawa } & \multirow{2}{*}{ Świerzawa } & \multirow{2}{*}{133,7} & 115,0 & 0,86 & 2012 & \\
\hline & & & & 152,0 & 1,14 & 1997 & \\
\hline
\end{tabular}

postrzeganie ma jej powszechnie stosowana nazwa sugerująca, że następne taka katastrofa może zdarzyć się za tysiąc lat (por. Tyszka, Zielonka 2017).

Analizowana w niniejszym opracowaniu powódź była dla mieszkańców zaskakująca i uciążliwa ze względu na przerwanie ciągłości funkcjonowania lokalnej społeczności i wywołane nią straty. Trwała jednak relatywnie krótko, zarówno jeśli chodzi o prze- 
Tab. 3. Powodzie w zlewni górnej Kaczawy w okresie od XV w. do drugiej dekady XXI w.

Table 3. Floods in the upper Kaczawa catchment area from the 15 th century till 2010 s

\begin{tabular}{|c|c|}
\hline $\begin{array}{l}\text { Wiek } \\
\text { Century }\end{array}$ & $\begin{array}{l}\text { Lata wystąpienia powodzi } \\
\text { Years with floods }\end{array}$ \\
\hline XV & $1445,1464,1480$ \\
\hline $\mathrm{XVI}$ & $\begin{array}{l}\text { 1501, 1515, 1567, 1568, 1569, 1570, 1573, } \\
1587,1593\end{array}$ \\
\hline XVII & 1608,1668 \\
\hline XVIII & $\begin{array}{l}\text { 1702, 1711, 1725, 1734, 1736, 1755, 1785, } \\
1797\end{array}$ \\
\hline XIX & $\begin{array}{l}1804,1813,1829,1833,1854,1871,1883 \text {, } \\
1897\end{array}$ \\
\hline$X X$ & 1926, 1977, 1997 \\
\hline$X X I$ & 2001, 2012, 2013 \\
\hline
\end{tabular}

Uwaga: pogrubioną czcionką zaznaczono powodzie katastrofalne.

Note: catastrophic floods in bold.

Źródto: Franczak, Działek (2017).

Source: Franczak, Działek (2017). mieszczanie się fali wezbraniowej, jak i o odczuwanie jej negatywnych konsekwencji trwające ok. tygodnia.

Badani mieszkańcy powracają do tego zdarzenia z dużą niechęcią, co wynika z traumatycznych przeżyć oraz powiązanych z nimi reakcji psychologicznych, m.in. mechanizmu redukcji dysonansu poznawczego (Działek 2013), kiedy poczucie bezradności wobec potencjalnej klęski skutkuje wypieraniem zagrożenia powodziowego. Potwierdza to również stosunkowo niewielkie zainteresowanie materiałami o powodzi udostępnionymi przez jej świadków w serwisie You'Tube, w szczególności brak cyklicznego powracania do tych zapisów audiowizualnych w okolicach rocznicy powodzi. Taką regularność w poszukiwaniu materiałów powodzi zaobserwowano natomiast $\mathrm{w}$ przypadku klęski, która nawiedziła Bogatynię w 2010 r.,

która jednak miała nie tylko gwałtowny przebieg, ale również zdecydowanie większy rezonans medialny. Obserwacji z Wojcieszowa nie można zatem uogólniać na inne przypadki powodzi błyskawicznych, gdyż pamięć społeczna może być uwarunkowana zróżnicowanym kontekstem lokalnym, np. odmiennym przebiegiem zjawiska, cechami społeczności lokalnych, w tym siłą lokalnych więzi społecznych, skalą obecności w mediach lokalnych i krajowych czy wreszcie - podejmowanymi po powodzi działaniami edukacyjnymi.

Przeprowadzone badania pokazują również, jak niepełny jest obraz przestrzennego zasięgu powodzi wśród mieszkańców różnych części zalanego obszaru. Ze względu na jej szybki przebieg mieszkańcy nie byli w stanie zaobserwować jej całego zasięgu, zwłaszcza że utrudniła ona możliwość przemieszczania się wzdłuż głównego szlaku komunikacyjnego przebiegającego w osi doliny. Wskazywany przez mieszkańców obszar powodzi jest zatem mniejszy niż w rzeczywistości i ulega dalszemu zmniejszeniu wraz z upływem czasu. Obraz powodzi oparty jest na bezpośrednich obserwacjach w trakcie powodzi, ale także uzupełniany o informacje pozyskane w trakcie rozmów w z innymi mieszkańcami, skupiając się jednak 
na najbardziej newralgicznych z punktu widzenia funkcjonowania społeczności, tj. głównej ulicy i mostu.

Powódź błyskawiczna, która dotknęła Wojcieszów w 2012 r., jako zdarzenie społeczne nie zapisało się na tyle wyraźnie w pamięci mieszkańców, by jej obraz funkcjonował w wyobrażeniach mieszkańców kilka lat po jej wystąpieniu. Wpływ na to miał niespodziewany charakter powodzi, co może wpisywać się w mechanizm potraktowania takiego zjawiska jako odstępstwa od reguły. Mogłyby temu zapobiec działania edukacyjne prowadzone w „oknie sposobności” bezpośrednio po wystąpieniu powodzi, które mogłyby pociągać za sobą wyciągnięcie wniosków z takiego katastrofalnego zdarzenia, przekładając się później na lepszy poziom przygotowania do kolejnej potencjalnej powodzi. Nie wykorzystano przy tym potencjału mediów społecznościowych, takich jak YouTube, gdzie pojawiły się jedynie amatorskie materiały mieszkańców miasta. Dobrym wzorcem w tym zakresie mogą być materiały przygotowane w Bieruniu przez lokalne stowarzyszenie mieszkańców poszkodowanych przez powódź w 2010 r., które opracowało film dokumentalny na temat tego zdarzenia, a następnie film edukacyjny o sposobach przygotowania się do kolejnej potencjalnej klęski. Z przeprowadzonych w Wojcieszowie wywiadów wynika jednocześnie, że elementem tego rodzaju działań edukacyjnych powinno być również wsparcie psychologiczne, tak by trauma powodzi nie wywoływała lęku i ignorowania zagrożenia, ale motywowała do działania i wzmacniała poczucie, że zmniejszenie negatywnych skutków powodzi jest możliwe.

\section{Literatura}

Bankoff G., 2004, Time is of the essence: Disasters, vulnerability and history, International Journal of Mass Emergencies and Disasters, 22, 3, 23-42.

Bartnik A., Jokiel P., 2012, Geografia wezbrań i powodzi rzecznych, Wydawnictwo Uniwersytetu Łódzkiego, Łódź.

Biernacki W., Bokwa A., Działek J., Padło T., 2009, Społeczności lokalne wobec zagrożén przyrodniczych i klęsk żywiotowych, IGiGP UJ, Kraków.

Biernacki W., Fiedeń Ł., 2017, Zmiennośćw czasieprzestrzennych wyobrażeń powodzi, [w:] J. Działek, W. Biernacki, R. Konieczny, Ł. Fiedeń, P. Franczak, K. Grzeszna, K. Listwan-Franczak,

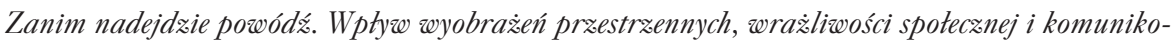
wania ryzyka na przygotowanie spoteczności lokalnych do powodzi, IGiGP UJ, Kraków.

Brennan-Horley C., 2010, Creative city mapping: Experimental applications of gis for cultural planning and auditing, University of Wollongong, Wollongong.

Brilly M., Polic M., 2005, Public perception of flood risks, flood forecasting and mitigation, Natural Hazards and Earth System Sciences, 5, 345-355. 
Bryndal T., 2009, Præeptywy maksymalne odnotowane podcæas gwattownych wezbrań, spowodowanych krótkotrwatymi ulewnymi opadami deszczu w matych slewniach karpackich, [w:] R. Bogdanowicz, J. Fac-Beneda (red.), Zasoby i ochrona wód. Obieg wody i materii w slewniach ræecsnych, Fundacja Rozwoju Uniwersytetu Gdańskiego, Gdańsk, 329-334.

Bryndal T., 2010, Parametry hydrologiczne wezbrań spowodowanych krótkotrwatymi intensywnymi opadami deszcะu w Polsce, Annales Universitatis Mariae Curie-Skłodowska, Sectio B: Geographia, Geologia, Mineralogia et Petrographia, 65, 43-71.

Bryndal T., 2011, Identyfikacja matych \&lewni podatnych na formowanie gwattownych wezbran na przyktadzie Pogórza Dynowskiego, Strzyżowskiego i Przemyskiego, Przegląd Geograficzny, 83, 1, 5-26.

Bryndal T., 2014a, Identyfikacja matych zlewni podatnych na formowanie gwattownych wezbrań w Karpatach Polskich, Prace Monograficzne UP, 690, Wydawnictwo Naukowe Uniwersytetu Pedagogicznego, Kraków.

Bryndal T., 2014b, Parametry hydrologiczne gwattownych wezbrań opadowo-nawalnych w matych zlewniach w polskiej, stowackiej i rumuńskiej cæęści Karpat, Przegląd Geograficzny, 86, 1, 5-21.

Bryndal T., 2015, Local flash floods in Central Europe: A case study of Poland, Norsk Geografisk Tidsskrift - Norwegian Journal of Geography, 69, 5, 288-298.

Bryndal T., Cabaj W., Gębica P., Kroczak R., 2010, Gwattowne wezbrania spowodowane nawalnymi opadami deszczu w zlewni potoku Wątok (Pogóræe Cięzkowickie), [w:] T. Ciupa, R. Suligowski (red.), Woda w badaniach geografic:nych, Instytut Geografii Uniwersytetu Jana Kochanowskiego, Kielce, 307-319.

Bryndal T., Franczak P., Kroczak R., Cabaj W., Kołodziej A., 2017, The impact of extreme rainfall and flash floods on the flood risk management process and geomorphological changes in small Carpathian catchments: A case study of the Kasiniczanka River (Outer Carpathians, Poland), Natural Hazards, 1-26.

Bucała A., Budek A., 2011, Zmiany morfologii koryt wskutek opadow ulewnych na przykładzie potoku Suszanka, Beskid Średni, Czasopismo Geograficzne, 82, 4, 321-332.

Buciak R., Pieniążek M., 2012, Spatial classification of rural areas in Poland, Geographia Polonica, 85, 1, 57-66.

Cha M., Kwak H., Rodriguez P., Ahn Y.-Y., Moon S., 2007, I Tube, You Tube, Everybody Tubes: Analyzing the World's Largest User Generated Content Video System, Proceedings of the 7th ACM SIGCOMM conference on Internet measurement, http://dl.acm.org/citation. cfm?id=1298309 (26.03.2017).

Cieplowski A., 1970, Maksymalne wielkości sptywów jednostkowych z deswcะow nawalnych, Przegląd Geograficzny, 15, 2, 179-193.

Colten C.E., Sumpter A.R., 2009, Social memory and resilience in New Orleans, Natural Hazards, $48,3,355-364$.

Covello V.T., 1991, Risk comparison and risk communication: issues and problems in comparing health and environmental risk, [w:] R.E. Kasperson, P.J.M. Stallen (red.), Communicating Risks to the Public, Kluwer, Dordrecht, 79-118. 
Dubicki A., 1999, Analiza maksymalnych stanów i przeptywów wody, [w:] A. Dubicki, H. Słota, J. Zieliński (red.), Dorzecze Odry. Monografia powodzi lipiec 1997, IMGW, Warszawa, 89-114.

Działek J., 2013, Cognitive dissonance, [w:] P.T. Bobrowsky (red.), Encyclopedia of Natural Ha:ards, Springer, Dordrecht, 98-99.

Działek J., Biernacki W., Konieczny R., Fiedeń Ł., Franczak P., Grzeszna K., Listwan-Franczak

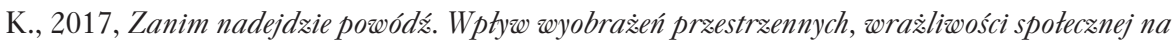
klęski zywiotowe i komunikowania ryzyka na przygotowanie spoteczności lokalnych do powodzi, IGiGP UJ, Kraków.

Felgentreff C., 2003, Post-disaster situations as „window of opportunity”? Post-flood perceptions and changes in the German Odra River region after the 1997 flood, Die Erde, 134, 163-180.

Franczak P., 2016, Hydrologiczne i geomorfologicæne skutki ekstremalnego opadu w maju 2014 roku w zlewni Rybnego Potoku (Masyw Babiej Góry), Annales Universitatis Mariae Curie-Skłodowska, Sectio B: Geographia, Geologia, Mineralogia et Petrographia, 70, 2, 63-81.

Franczak P., 2017, Rola katastrofalnych wezbrań w ksztattowaniu morfologii koryt w matych slewniach górskich, na præykładzie zdarzenia z maja 2014 r. w zlewni górnej Skawicy, Leśne Prace Badawcze, 78, 1, 28-38.

Franczak P., Działek J., 2017, Przebieg powodzi w badanych obsæarach i ich konsekwencje, [w:] J. Działek, W. Biernacki, R. Konieczny, Ł. Fiedeń, P. Franczak, K. Grzeszna, K. Listwan-Franczak, Zanim nadejdzie powódঞ. Wphyw wyobrażen præestrzennych, wrażliwości spotecznej i komunikowania ryzyka na przygotowanie spoteczności lokalnych do powodzi, IGiGP UJ, Kraków.

Franczak P., Listwan-Franczak K., 2016, Powódź w zlewni Miedzianki (zlewnia Nysy Łużyckiej) w sierpniu 2010 roku. Dobra praktyka w redukcji ryzyka powodziowego w matych slewniach górskich, w których wystapiła powódঞ́ btyskawična, [w:] P. Franczak, P. Krąż, J. Liro, M. Liro, K. Listwan-Franczak (red.), Wspótczesne problemy i kierunki badawcæe w geografii, 4, IGiGP UJ, Kraków, 55-84.

Gorczyca E., Wrońska-Wałach D., 2008, Transformacja małych zlewni górskich podczas opadowych zdarzeń ekstremalnych (Bieszczady), Landform Analysis, 8, 25-28.

Gorczyca E., Krzemień K., Wrońska-Wałach D., Sobucki M., 2013, Channel changes due to extreme rainfalls in the Polish Carpathians, [w:] D. Lończy (red.), Geomorphological impacts of extreme weather, case Studies from Central and Eastern Europe, Springer, Dordrecht, 23-35.

Gorzkowski R., 2008, Powód:́ 1608 roku, Echo Złotoryi, 6, 14-15.

Grzeszna K., 2017, Materiaty publikowane w YouTube - wirtualnym, spotecznym „archiwum” lokalnych powodzi, [w:] J. Działek, W. Biernacki, R. Konieczny, Ł. Fiedeń, P. Franczak, K. Grzeszna, K. Listwan-Franczak, Zanim nadejdzie powód※́. Wptyw wyobrażeń przestrzennych, wrä́liwości spotecznej i komunikowania ryzyka na przygotowanie spoteczności lokalnych do powodzi, IGiGP UJ, Kraków.

Hong Y., Adhikari P., Gourley J.J., 2013, Flash flood, [w:] P.T. Bobrowsky (red.), Encyclopedia of Natural Ha:ards, Springer, London, 324-325. 
Izmaiłow B., Kamykowska M., Krzemień K., 2008, Geomorfologiczna rola katastrofalnych wezbrań w transformacji górskiego systemu korytowego na przykładzie Wilszni (Beskid Niski), [w:] B. Izmaiłow (red.), Przyroda - Čłowiek - Bóg, IGiGP UJ, Kraków, 69-81.

Klejnowski R., 2012a, Komentar* synoptyka \& dnia 4 lipca 2012 r., http://weather.icm.edu.pl/ komentarze/index1.php? date=2012-07-04 (10.10.2016).

Klejnowski R., 2012b, Komentars synoptyka \& dnia 5 lipca 2012 r., http://weather.icm.edu.pl/ komentarze/index1.php?date=2012-07-05 (10.10.2016).

Kondracki J., 2002, Geografia regionalna Polski, Wydawnictwo Naukowe PWN, Warszawa.

Konieczny R., Działek J., Siudak M., Biernacki W., 2016, Dziatania wtaścicieli domów dla ograniczenia skutków powodzi oraz ich motywacje, [w:] T. Walczykiewicz (red.), Problemy planowania w gospodarce wodnej i oceny stanu hydromorfologicznego rzek, IMGW-PIB, Warszawa, 171-189.

Kowalczuk I., Mykhnowych A., Pylypovych O., Rud'ko G., 2013, Extreme exgenus processes in Ukrainian Carpathians, [w:] D. Lończy (red.), Geomorphological impacts of extreme weather, case studies from Central and Eastern Europe, Springer, Dordrecht, 53-66.

Krasovskaia I., Gottschalk L., Sælthun N.R., Berg H., 2001, Perception of the risk of flooding: The case of the 1995 flood in Norway, Hydrological Sciences Journal, 46, 6, 855-868.

Kuhlicke C., 2010, The dynamics of vulnerability: Some preliminary thoughts about the occurrence of 'radical surprises' and a case study on the 2002 flood (Germany), Natural Hazards, 55 (3), 671-688.

Kuhlicke C., Steinführer A., 2015, Preface: Building social capacities for natural hazards: An emerging field for research and practice in Europe, Natural Hazards Earth System Science, 15, 2359-2367.

Lambor J., 1971, Hydrologia inżynierska, Arkady, Warszawa.

Lenart W., 1993, Opad atmosferyczny, [w:] U. Soczyńska (red.), Podstawy hydrologii, Wydawnictwa Uniwersytetu Warszawskiego, Warszawa, 101-116.

MPHP - Rastrowa mapa podziatu hydrograficznego Polski, 2010, Krajowy Zarząd Gospodarki Wodnej, Warszawa.

Olędzki R., 2012a, Komentarzsynoptyka \& dnia 2 lipca 2012 r., http://weather.icm.edu.pl/komentarze/ index1.php? date=2012-07-02 (10.10.2016).

Olędzki R., 2012b, Komentar: synoptyka \& dnia 3 lipca 2012 r., http://weather.icm.edu.pl/ komentarze/index1.php? date=2012-07-03 (10.10.2016).

Ostrowski J., Czarnecka H., Głowacka B., Krupa-Marchlewska J., Zaniewska M., Sasim M., Moskwiński T., Dobrowolski A., 2012, Nagte powodzie lokalne (flash flood) w Polsce i skala ich zagrożen, [w:] H. Lorenc (red.), Klęski żywiotowe a bezpieczeństwo wewnętrzne kraju, IMGW-PIB, Warszawa, 123-149.

Parczewski J., 1960, Warunki występowania gwattownych wezbrań na matych ciekach, Wiadomości Służby Hydrologicznej i Meteorologicznej, 8, 1-159.

Pociask-Karteczka J., Żychowski J., 2014, Powodzie btyskawiczne (flash floods) - przyczny i przebieg, [w:] T. Ciupa, R. Suligowski (red.), Woda w mieście, Monografie Komisji Hydrologicznej PTG, 2, 213-226.

Renn O., 2008, Risk governance: Coping with uncertainty in a complex world, Earthscan, London. 
Romanowicz R.J., Nachlik E., Januchta-Szostak A., Starkel L., Kundzewicz Z.W., Byczkowski A., Kowalczak P., Żelaziński J., Radczuk L., Kowalik P., Szamałek K., 2014, Zagrożenia zwiqzane z nadmiarem wody, Nauka, 1, 123-148.

Rucińska D., 2012, Ekstremalne zjawiska przyrodnicze a świadomośćspoteczna, Wydział Geografii i Studiów Regionalnych UW, Warszawa.

Rucińska D., 2014, Interdyscyplinarność i uniwersalność koncepcji redukcji ryzyka klęsk żywiotowych, Prace i Studia Geograficzne, 55, 119-131.

Rufat S., Tate E., Burton C.G., Maroof A.S., 2015, Social vulnerability to floods: Review of case studies and implications for measurement, International Journal of Disaster Risk Reduction, 14, 4, 470-486.

Ruin I., Gaillard J.-C., Lutoff C., 2007, How to get there? Assessing motorists' flash flood risk perception on daily itineraries, Environmental Hazards, 7, 3, 235-244.

Siegrist M., Gutscher H., 2008, Natural hasards and motivation for mitigation behavior: People cannot predict the affect evoked by a severe flood, Risk Analysis, 28, 3, 771-778.

Simonsen T.M., 2011, Categorising YouTube, Meide Kultur: Journal of Media and Communication Research, 51, 72-93.

Smith K., 2001, Environmental Hazards: Assessing Risk and Reducing Disaster, Routledge, London-New York.

Stockmann P., 1892, Geschichte des Dorfes und des Kirchspiels Kauffung: Festschrift «um 150 jährigen Jubiläum der evangelischen Gemeinde am Sonntag Jubilate 1892, Rettungsanst, SchreiberhauDiesdorf.

Tobin G.A., Burrel E.M., 1997, Natural hazards: Explanation and integration, Guilford Press, New York.

Tyszka T., Zielonka P., 2017, Large risks with low probabilities: Perceptions and willingness to take preventive measures against flooding, IWA Publishing, London.

Wachinger G., Renn O., 2010, Risk perception and natural ha:ards: CapHaz-Net WP3 report, DIALOGIK, Stuttgart, http://caphaz-net.org/outcomes-results (10.05.2016).

Wilson G.A., 2013, Community resilience, social memory and the post-2010 Christchurch (New Zealand) earthquakes, Area, 45, 2, 207-215.

Woś A., 1999, Klimat Polski, Wydawnictwo Naukowe PWN, Warszawa.

Pawet Franczak, Jarostaw Dziatek, Łukasz Fiedeń

Uniwersytet Jagielloński

Instytut Geografii i Gospodarki Przestrzennej

p.franczak@uj.edu.pl;jarek.dzialek@uj.edu.pl; lukasfieden@vp.pl

Wojciech Biernacki

Akademia Wychowania Fizycznego im. Bronistawa Czecha w Krakowie

Wydziat Turystyki i Rekreacji

wojciech.stanislaw.biernacki@gmail.com 
